\title{
Evaluating the use of local ecological knowledge to monitor hunted tropical- forest wildlife over large spatial scales
}

\author{
Luke Parry $^{1,2}$ and Carlos A. Peres ${ }^{3}$
}

\begin{abstract}
Monitoring the distribution and abundance of hunted wildlife is critical to achieving sustainable resource use, yet adequate data are sparse for most tropical regions. Conventional methods for monitoring hunted forest-vertebrate species require intensive in situ survey effort, which severely constrains spatial and temporal replication. Integrating local ecological knowledge (LEK) into monitoring and management is appealing because it can be cost-effective, enhance community participation, and provide novel insights into sustainable resource use. We develop a technique to monitor population depletion of hunted forest wildlife in the Brazilian Amazon, based on the local ecological knowledge of rural hunters. We performed rapid interview surveys to estimate the landscape-scale depletion of ten large-bodied vertebrate species around 161 Amazonian riverine settlements. We assessed the explanatory and predictive power of settlement and landscape characteristics and were able to develop robust estimates of local faunal depletion. By identifying speciesspecific drivers of depletion and using secondary data on human population density, land form, and physical accessibility, we then estimated landscape- and regional-scale depletion. White-lipped peccary (Tayassu pecari), for example, were estimated to be absent from $17 \%$ of their putative range in Brazil's largest state (Amazonas), despite $98 \%$ of the original forest cover remaining intact. We found evidence that bushmeat consumption in small urban centers has far-reaching impacts on some forest species, including severe depletion well over $100 \mathrm{~km}$ from urban centers. We conclude that LEK-based approaches require further field validation, but have significant potential for community-based participatory monitoring as well as cost-effective, large-scale monitoring of threatened forest species.
\end{abstract}

Key Words: Amazon; Brazil; game; harvesting; hunting; interviews; large mammals

\section{INTRODUCTION}

Conserving biodiversity requires monitoring of species, habitats, and human dimensions of social-ecological systems (Danielsen et al. 2009). Monitoring is important because it enables detection of unexpected change, can raise awareness among citizens and policy makers, and allows management interventions to be developed and evaluated (Wintle et al. 2010, Jones et al. 2013).

Global-scale analyses can provide useful insights into patterns of biodiversity loss (Collen et al. 2009) but they cannot elucidate local to regional scale heterogeneity of threats or the effectiveness of conservation interventions. Effectiveness is unknown without robust and repeatable monitoring systems in place, with sufficient rigor, spatial replication, and long-term sustainability (Jenkins et al. 2003, Lindenmayer and Likens 2009). However, financial and human resources are generally limited, particularly in developing countries (Waldron et al. 2013), and the cost-effectiveness of biodiversity surveys varies widely by taxa (Gardner et al. 2008). Although remote sensing can detect tropical forest loss and some forms of degradation, it overlooks cryptic threats such as overhunting (Peres et al. 2006). Tropical forest vertebrates are declining faster than forest coverage (Jenkins et al. 2003), therefore quantifying deforestation alone would underestimate faunal depletion. Because of their key ecological roles (Stoner et al. 2007) and nutritional importance (Milner-Gulland et al. 2003), considerable in situ effort has been dedicated to monitoring tropical forest vertebrates.

Monitoring the distribution and abundance of biodiversity at landscape scales is difficult and expensive (Jones 2011), which constrains spatial and temporal replication (Danielsen et al. 2005). Line-transect censuses are often used to survey tropical forest wildlife (e.g., Peres and Palacios 2007) but they require intensive sampling effort (de Thoisy et al. 2008), and are often restricted to only a few sites (Ceballos and Ehrlich 2002). Low detection rates tend to derive abundance estimates with high levels of uncertainty for the rarer species of greater conservation concern (Peres 2000, Munari et al. 2011), limiting their potential for detecting changes in abundance (Plumptre 2000). In contrast, locally based approaches can provide cost-effective monitoring of species distribution and abundance over large scales (Silvertown 2009) and can offer long-term sustainability by empowering local stakeholders to better manage their own natural resources (Danielsen et al. 2009, Luzar et al. 2011).

The relative abundance (or presence-absence) of forest species can be inferred from monitoring hunters' catch per unit effort (CPUE), allowing spatial and temporal comparisons (Puertas and Bodmer 2004, Sirén et al. 2004). This is arguably an effective method because the observer performance and overall survey effort of adept central-place hunters often exceed those of conventional biodiversity surveys. However, CPUE estimates can be biased by hunting technology, habitat type, and the preyselectivity of hunters (Rist et al. 2008, Levi et al. 2009, Parry et al. 2009). Furthermore, game harvest studies may require at least 12 months of intensive monitoring of hunter effort and offtake. Consequently, CPUE estimates are often available from only a single community (e.g., Sirén et al. 2004), limiting the potential to make reliable predictions about the status of exploited populations across broader geographic scales. Developing methods that can be replicated around many communities is therefore vital for effective conservation strategies because multiple human and biophysical drivers affect wildlife populations (Meijaard et al. 2011).

${ }^{1}$ Lancaster Environment Centre, Lancaster University, UK, ${ }^{2}$ Universidade Federal do Pará (UFPA), Núcleo de Altos Estudos Amazonicos (NAEA), Belém, Brazil, ${ }^{3}$ School of Environmental Sciences, University of East Anglia, Norwich, UK 
New techniques have emerged that utilize local or traditional ecological knowledge (hereafter, LEK) to monitor species distributions and population trends over time (Ferguson et al. 1998, Anadón et al. 2009, Turvey et al. 2014). Empirical observations and ecological knowledge of local experts can provide cost-effective and robust understanding of natural systems that is equal to or exceeds that of current scientific knowledge (Gagnon and Berteaux 2009, Meijaard et al. 2011, Beaudreau and Levin 2014). Integrating LEK into monitoring and management (Moller et al. 2004) is also appealing because it can enhance community participation (Ban et al. 2009) and provide novel insights into sustainable resource use (Berkes and Folke 1998). We have developed a technique to monitor the depletion of hunted forest wildlife over vast tracts of forest across the Brazilian Amazon, based on rapid interviews with rural hunters to determine occupancy zones. We evaluated the extent to which species depletion around the 161 settlements we visited is determined by human population and landscape characteristics and explore whether these local trends hold at the landscape scale. Finally, we estimated the depletion of our study species for the entire state of Amazonas, an important first step in developing tools for monitoring hunted species over vast tropical forest areas with limited human and financial resources (Waldron et al. 2013, Parry et al. 2014). Amazonas is the largest state, 1.57 million $\mathrm{km}^{2}$, in Brazil and has $97.6 \%$ of its original forest cover still intact (Instituto Nacional de Pesquisas Espaciais 2013).

\section{METHODS}

\section{Field surveys}

We assessed the impacts of hunting along seven major tributaries and subtributaries of the Amazon (= Solimões) river within the state of Amazonas (Fig. 1A), selected at varying distances from Manaus, the state capital. As preselection criteria, these rivers were distant from one another, had an urban center near to the confluence with the larger river, were not be bisected by roads, and avoided indigenous territories or protected areas. For surveys, which were 10-21 days each from February to November 2007, we used a boat and locally assembled crew to travel along the main fluvial axis defined as the entire riparian zone of human occupation from the local urban center to the last active household on any given river ( $\leq 749 \mathrm{~km}$ travel distance). Our crew members were familiar with the local populace and had many years, often lifelong, experience along a given river, which facilitated the identification of discrete settlements and aided in reliable communication with river dwellers. We mapped all settlements, including isolated households (total $=383$ ) heading upriver, using a GPS. Travelling downriver, we conducted detailed interviews at 161 of these settlements (range $=1-281$ households, mean $=8.3$, median $=3$ ), selected by random stratified sampling.

\section{Assessing depletion using local ecological knowledge}

We sought to evaluate the depletion of hunted forest wildlife using the lifelong field experience and recent observations of rural hunters (sensu Turvey et al. 2014). By asking Amazonian hunters to identify the nearest location in which they had directly or indirectly encountered a particular species, we were drawing on their LEK, defined as the knowledge and insights acquired through extensive observation of an area or species (Huntington 2000). Consequently, our approach can be distinguished from studies of traditional ecological knowledge (TEK), which examine the body of knowledge, practice, or belief evolving by adaptive processes and handed down through generations by cultural transmission (Berkes et al. 2000), e.g., social taboos (Colding and Folke 2001). We focused on a specific dimension of LEK, i.e., a hunter's ability to identify species presence in their local area using direct sightings or indirect signs. Other forms of LEK have also been used to monitor wildlife populations, including hunter assessments of targeted populations, e.g., demography, body condition, and catch-per-unit effort (Bodmer and Robinson 2004, Moller et al. 2004, Rist et al. 2008).

Fig. 1. (A) Map of rivers surveyed within Amazonas State, Brazil, with inset red box of Pauiní. Numbers 1-7 refer to the following rivers (in order): Rio Aracá, Rio Abacaxí, Rio Tefé, Rio Coarí, Rio Jacaré, Rio Pauiní, and Rio Ituxí. (B) Depletion of woolly monkeys (Lagothrix spp.) around visited settlements (reported depletion distances) and unvisited settlements (estimated depletion distances) along a section of the lower Rio Pauiní. (C) Same as above, for collared peccary (Pecari tajacu).
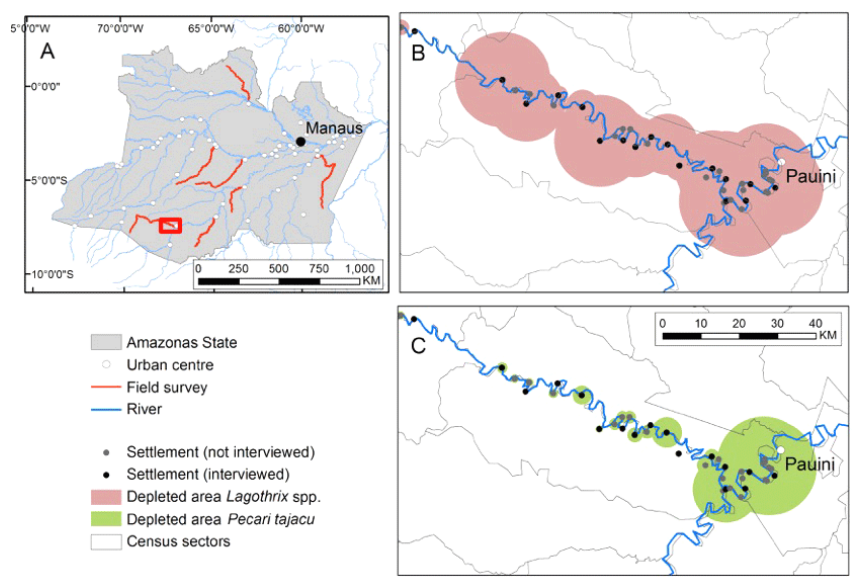

Standardized questions on faunal presence/absence targeted all available hunters in a settlement (range $=1-5$ hunters interviewed) and other community members with many years of local knowledge of wildlife and hunting. We used these questions to assess the local depletion of ten Amazonian game vertebrate species or congeners, including four primates, four ungulates, one game bird, and one testudine reptile (Appendix 1, Table A1), which vary in their known preference to hunters (Jerozolimski and Peres 2003) and tolerance of human exploitation (Peres 2000). We sought to establish the minimum depletion zone (Flesher and Ley 1996) around each settlement for each of the game species that were familiar to hunters and other knowledgeable community members. Informants were asked to identify the nearest place where a species had been seen, heard (place of origin of the sound), or otherwise detected indirectly using tracks or feces during the last 12 months. This method was used to determine the area in which a given species was absent. Hunters generally identified a locally known forest area, such as a secondgrowth patch or Brazil-nut tree (Bertholletia excelsa) cluster where they had detected a given species. We established the quickest method of getting there, i.e., on foot, by motorized or unmotorized canoe, and ascertained the minimum travel time when the hunter was travelling directly and unencumbered. We then calculated an approximate distance from the settlement using mean travel speeds recorded with a GPS over several years at 
Table 1. Results of hierarchical partitioning, an analytical procedure that was used to separate the independent explanatory effects of human settlement and landscape predictors on the depletion (estimated by nearest encounter distance) of 10 Amazonian largevertebrates. Model fit is approximated using generalized additive models (GAM) measures and significant effects $(*=p<0.05)$ identified using randomizations. Species codes refer to (in order): Tapirus terrestris, Cebus apella, Lagothrix spp., Mazama americana, Pecari tajacu, Tayassu pecari, Mitu/Crax spp., Pithecia spp., Chelonoidis spp., and Ateles spp.

\begin{tabular}{|c|c|c|c|c|c|c|c|c|c|c|c|c|}
\hline \multirow[b]{2}{*}{ Variables } & \multirow[b]{2}{*}{$\mathrm{p}<0.05(\mathrm{n})$} & \multicolumn{10}{|c|}{ Species } & \multirow[b]{2}{*}{ Mean } \\
\hline & & Tter & Cape & Lago & Mame & Ptaj & Tpec & Mitu & Pith & Chel & Atel & \\
\hline Model fit $\left(\mathrm{R}^{2}\right)$ & & 0.79 & 0.51 & 0.92 & 0.21 & 0.87 & 0.84 & 0.69 & 0.26 & 0.80 & 0.93 & 0.68 \\
\hline \multicolumn{13}{|c|}{ Main predictors - percentage of independent effects explained } \\
\hline People $\mathrm{km}^{-2}$ & pos. (6) & $25^{*}$ & $29 *$ & $16^{*}$ & $33^{*}$ & $29 *$ & $13^{*}$ & 4 & 1 & 2 & 8 & 16 \\
\hline City-distance $(\mathrm{km})$ & neg. (6) & $17^{*}$ & $21 *$ & $11^{*}$ & 1 & 4 & $8^{*}$ & $6^{*}$ & $17^{*}$ & 5 & 2 & 9 \\
\hline Households (n) & pos. (3) & 4 & 3 & $16^{*}$ & 4 & 3 & $13^{*}$ & $22 *$ & 7 & 1 & 1 & 8 \\
\hline Terra firme $(\%)$ & neg. (6) & $11^{*}$ & 3 & $11^{*}$ & $4^{*}$ & $7 *$ & $8^{*}$ & 3 & 3 & $13^{*}$ & 2 & 6 \\
\hline Total $(\%)$ effects & & 58 & 57 & 54 & 43 & 43 & 42 & 34 & 27 & 21 & 14 & 39 \\
\hline Vars $\mathrm{p}<0.05$ & & 3 & 2 & 4 & 2 & 2 & 4 & 2 & 1 & 1 & 0 & 2.1 \\
\hline \multicolumn{13}{|c|}{ Additional predictors - percentage of independent effects explained } \\
\hline River identity & $\mathrm{n} / \mathrm{a}(6)$ & 13 & 19 & $21 *$ & 7 & $23 *$ & 9 & $22 *$ & $51 *$ & $60 *$ & $80 *$ & 30 \\
\hline Forest-distance & $\operatorname{mix}(2)$ & 21 & $19 *$ & 8 & 44 & 29 & 14 & $14^{*}$ & 3 & 6 & 5 & 16 \\
\hline Settlement growth $(\Delta)$ & pos. (2) & 2 & 3 & 14 & 4 & 4 & $31 *$ & $27 *$ & 9 & 4 & 1 & 10 \\
\hline Settlement age (yrs) & pos. (1) & $6^{*}$ & 2 & 3 & 1 & 1 & 4 & 4 & 10 & 9 & 0 & 4 \\
\hline Total $(\%)$ effects & & 42 & 43 & 46 & 57 & 57 & 58 & 66 & 73 & 79 & 86 & 61 \\
\hline Vars $\mathrm{p}<0.05$ & & 1 & 1 & 1 & 0 & 1 & 1 & 3 & 1 & 1 & 1 & 1.1 \\
\hline Total sig. terms & & 4 & 3 & 5 & 2 & 3 & 5 & 5 & 2 & 2 & 1 & 3.2 \\
\hline
\end{tabular}

multiple Amazonian sites (walking: $4 \mathrm{~km} \mathrm{~h}^{-1}$, unmotorized canoe: $5 \mathrm{~km} \mathrm{~h}^{-1}$, motorized canoe: $\left.9 \mathrm{~km} \mathrm{~h}^{-1}\right)$.

\section{Field data reliability}

Identifying local experts can be problematic when recording LEK (Davis and Wagner 2003). However, hunting is practiced by most able-bodied men in rural Amazonia, and thus locating knowledgeable informants was straightforward (Luzar et al. 2011). However, the motives of interviewees can bias responses, especially when there are perceived conflicts of interest with the interviewer (Danielsen et al. 2005, Grant and Berkes 2007). We therefore used several approaches to identify and minimize bias in the data we recorded from hunters. First, we had a general discussion about our research objectives with hunters and community members prior to interviews (conducted by LP). Parry identified himself as a researcher independent of any governmental organization, such as the Brazilian Institute for the Environment and Renewable Natural Resources (IBAMA), which is responsible for enforcing environmental laws, although subsistence hunting is not illegal in Brazil. We then used triangulation techniques to verify data quality and respondent reliability (Jick 1979). For example, recall of recent offtake (kills) was used to provide internal validation of depletion distances and vice versa (Parry 2009). For instance, we would expect hunters to occasionally kill large mammal species if present nearby. We cross-validated responses (Meijaard et al. 2011), including familiarity with species and hunting activity, by later asking our boat crews, all of whom had experience of forest extraction and were often present during interviews, and inhabitants of neighboring settlements about the hunting patterns of a given settlement. On no occasion did we perceive, nor boat crews or residents report, any suspicion over the reliability of the depletion distances reported. On the rare occasions that hunters from the same settlement disagreed over minimal depletion distances, we used the estimate of the hunter judged to be most reliable, which was generally the individual who spent more time hunting.

\section{Predictor variables}

We tested the explanatory and predictive power of human settlement variables and landscape variables (Table 1) on the depletion distances of the study species (see Appendix 1). Human settlement variables included human population density (HPD; people per $\mathrm{km}^{2}$ within five $\mathrm{km}$ radius), settlement size (households), settlement growth ( $\Delta$ households 1991-2007), and settlement age (years since establishment). Landscape variables included distance $(\mathrm{km})$ to the nearest primary forest, upland terra firme coverage (TF; \% within five $\mathrm{km}$ radius), fluvial travel distance $(\mathrm{km})$ to the nearest urban center (DIS), and river identity. We also included population census sectors as a larger-scale unit of analysis. Municipalities are the local units of government in Brazil, each with an administrative urban center and surrounding rural area, and are subdivided into these sectors for the purposes of the national census. We measured three characteristics of each sector: HPD derived from the 2007 national census (IBGE 2007), DIS (Parry et al. 2010), and TF coverage (Hess et al. 2003).

\section{Data analysis}

We first assessed the independent effects of the eight candidate explanatory variables on local faunal depletion. Traditional model selection techniques are ill suited to high levels of multicollinearity among explanatory variables (Graham 2003), so we used an approach called hierarchical partitioning (see Appendix 1). We aimed to develop predictive models of the proportion of census sectors depleted of each game species across Amazonas. We sought to verify relationships between three predictors (HPD, TF, DIS) and faunal depletion for the 41 sectors for which we had interview data from visited settlements, and spatial locations and population size from all unvisited settlements. These sectors captured high levels of variation in HPD $\left(0.002>10.6\right.$ people $\left.\mathrm{km}^{2}\right)$, TF $(0.0>0.99)$ and DIS $(16>$ $749 \mathrm{~km})$.

To estimate depletion within sectors, we needed to predict the size of depletion zones around unvisited but mapped settlements (n 
= 222). We first developed minimal generalized linear models (GLMs) of depletion distances around visited settlements, using the four variables for which we had measures for both visited and unvisited settlements (HPD, number of households, TF, DIS). Using ArcGIS 10.1 (ESRI 2012), we combined predicted depletion zones around nonvisited settlements with reported depletion zones around visited settlements (Fig. 1B, C) to estimate sector-level depletion (proportion, see Appendix 1). Finally, to predict faunal depletion in census sectors elsewhere in Amazonas, we exported our GIS-derived sector depletion estimates and fitted minimal GLMs to predict census sector depletion using the three variables for which we have measures for all sectors $(n=1752$ rural census sectors; variables: HPD, TF, DIS). We exported our predictions to a GIS and removed depletion estimates from census sectors outside of the known geographic range polygons of each of our study species, based on spatial information from http:// www.natureserve.org/infonatura/ (mammals) and http://www. iucnredlist.org/ (birds). All statistical analyses were implemented using the statistical platform R 3.1.0 (Gentleman and Ihaka 2014).

\section{RESULTS}

\section{Local depletion}

Overall, the greatest depletion distances were for, in descending order, forest tortoise (Chelonoidis spp.), spider monkeys (Ateles belzebuth and $A$. chamek), woolly monkeys (Lagothrix cana, $L$. poeppigii, and L. lagothricha), tapir (Tapirus terrestris), and both species of peccaries (Pecari tajacu and Tayassu pecari; Fig. 2A). The smallest depletion distances were for the two medium-sized primates, i.e., saki monkeys (Pithecia irrorata and P. albicans) and capuchin monkey (Cebus apella), curassows (Mitu tuberosum, $M$. tomentosum, Crax globulosa, and C. alector), and red brocket deer (Mazama americana).

Fig. 2. (A) Boxplots of depletion distances around settlements, with 95th percentiles. (B) Percentage of geographic range (filled circles) within the State of Amazonas estimated to be completely depleted of each species and the absolute range area estimated to be either depleted (filled bars) and occupied (empty bars).

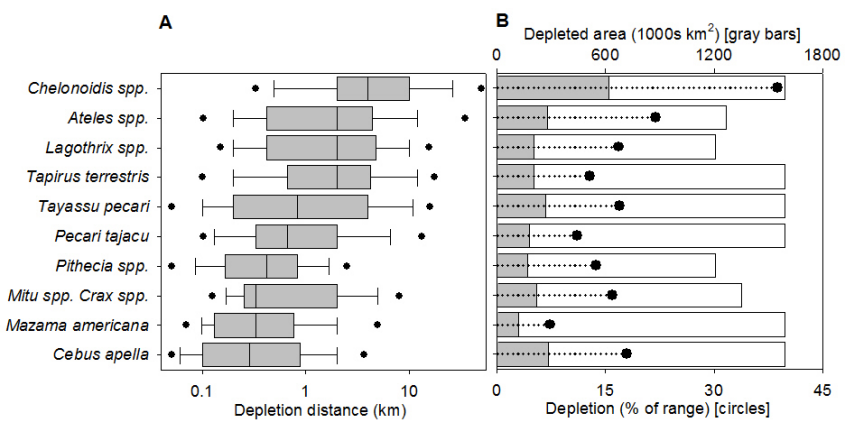

\section{Explaining depletion around settlements}

Our eight candidate human-settlement and landscape variables explained a large proportion of the variation in depletion distances of large-bodied forest-vertebrate species, with model fits of $R^{2} \geq 0.51$ for eight species (lower $R^{2}$ values for red brocket deer and saki monkeys; Table 1). The number of significant predictors per species $(\mathrm{p}<0.05$, following randomization of hierarchical partitioning results) ranged from five (woolly monkeys, white-lipped peccary, and curassow) to one (spider monkeys). Four predictors (HPD, DIS, TF, and river identity) were the most important because they each explained significant variation in depletion for six species. For these species, the mean percentage of independent effects explained by these variables was: $24 \%$ (HPD), $13 \%$ (DIS), $9 \%$ (TF), and 43\% river identity. Human population density was a significant depletion driver for the four ungulates, capuchin monkey, and woolly monkeys. Tapir, white-lipped peccary, three primates, (woolly monkeys, capuchin monkey, and saki monkeys) and curassows were significantly less depleted around settlements farther from urban centers. The four ungulates plus woolly monkeys and tortoise were significantly less depleted in areas containing more TF. Woolly monkeys, whitelipped peccary, and curassows were significantly more depleted around larger settlements, whereas tapir were more heavily depleted around older settlements.

River identity was a significant determinant of depletion for six species, largely reflecting the whole or near absence of many species on the Rio Aracá, a tributary of the Rio Negro. Whitelipped peccary and curassow were significantly more depleted around rapidly growing settlements (mean effects $=29 \%$ for these species). When settlements were farther from primary forest, curassow could only be encountered significantly farther away, whereas capuchin monkey were encountered significantly closer to settlements (mean effects $=17 \%$ ). Tapir were significantly more depleted around older settlements (6\% of effects). In summary, by separating the independent effects of collinear landscape and settlement variables, we show that HPD is a major driver of faunal depletion around rural settlements and that many species are significantly less depleted in areas that are unflooded and farther from urban centers.

\section{Predicting depletion around settlements}

Predictive (minimal GLM) models of settlement-level depletion distances were restricted to only four variables to estimate depletion around unvisited settlements along the rivers we surveyed (Appendix 1, Table A3). These variables explained a reasonably high amount of the variance in detection distances for the four ungulates (tapir: $\mathrm{R}^{2}=0.68$; red brocket deer: $\mathrm{R}^{2}=0.67$; white-lipped peccary: $R^{2}=0.50$; collared peccary: $\left.R^{2}=0.43\right)$, and woolly monkeys $\left(\mathrm{R}^{2}=0.44\right)$. Model fits were lower for capuchin monkeys $\left(\mathrm{R}^{2}=0.31\right)$ and curassow $\left(\mathrm{R}^{2}=0.30\right)$ and very low for saki monkeys, tortoises, and spider monkeys.

Nine species were significantly less depleted around more remote settlements, with stronger effects (coefficients) for the four ungulates (Fig. 3A). For example, at $50 \mathrm{~km}$ of travel distance from the nearest urban center, we predicted that tapir would only be encountered $8.6 \mathrm{~km}$ from a settlement (Fig. 4A). Depletion distance declines to $4.9 \mathrm{~km}$ at $100 \mathrm{~km}$ from town and just $0.5 \mathrm{~km}$ around settlements $300 \mathrm{~km}$ from town. Nine species were significantly more depleted in more populous areas. Although both settlement size (Fig. 3C) and HPD (Fig. 3D) were significant depletion drivers for white-lipped peccary and woolly monkeys, the depletion of other species was determined either by settlement size (strongest effect for tortoise and woolly monkeys) or HPD (strongest for white-lipped peccary). Predictions for woolly monkeys show that the depletion distance around a settlement comprised of 20 households $(9.7 \mathrm{~km})$ is more than twice that of a settlement of only 5 households $(4.2 \mathrm{~km}$; Fig. $4 \mathrm{E})$. 
Fig. 3. Coefficients from minimal generalized linear models (GLMs) of depletion distances of hunted vertebrates around 161 Amazonian settlements for the following predictor variables: (A) Travel distance from nearest urban settlement (km); (B) Percentage of terra firme upland within a $5 \mathrm{~km}$ radius; (C) Number of households in the settlement; (D) Human population density (people $\mathrm{km}-2$ ) within a $5-\mathrm{km}$ radius. Shading indicates significance levels (black: $p<0.001$; dark gray: $\mathrm{p}<0.01$; light gray: $\mathrm{p}<0.05$; white: $\mathrm{p}<0.1$ ).

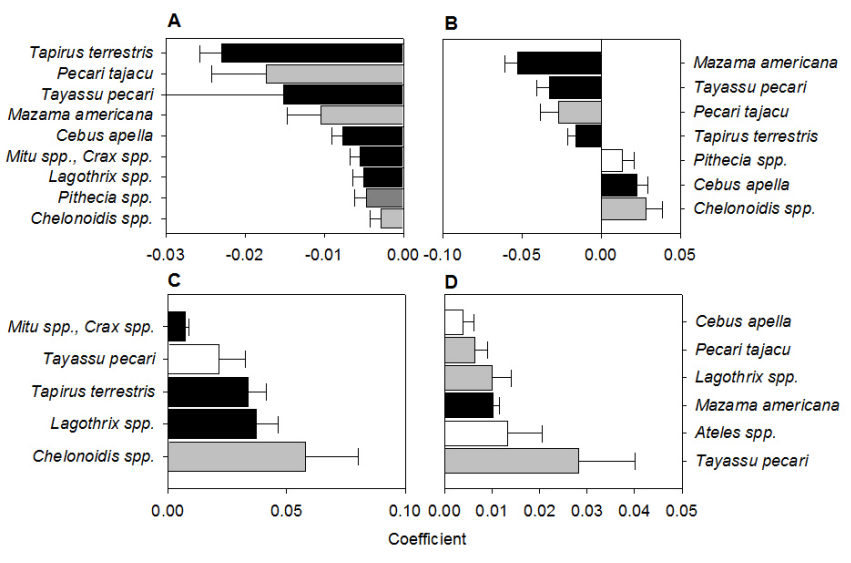

Terra firme coverage had a negative effect on the depletion of the four ungulates (Fig. 3B). In seasonally flooded (várzea) dominated areas (e.g., only $25 \% \mathrm{TF}$ ), we predicted that whitelipped peccary would only be encountered $6.4 \mathrm{~km}$ from a settlement, compared to $1.2 \mathrm{~km}$ from settlements in areas dominated $(75 \%)$ by TF (Fig. 4D). Overall, predictive models showed that nine species were significantly less depleted around settlements far from urban centers and more depleted in areas with more human inhabitants. The four ungulate species were more depleted in areas dominated by seasonally flooded forest. Depletion estimates from interviews and predicted depletion around unvisited settlements show marked differences in the size of depletion zones between species that are more sensitive (e.g., woolly monkeys; Fig. 1B) and less sensitive (e.g., collared peccary (Pecari tajacu; Fig. 1C) to hunting pressure.

\section{Predicting census sector depletion}

Minimal GLMs provided robust predictions of faunal depletion within the 41 visited census sectors for all species $R_{\operatorname{dev}}{ }^{2} \geq 0.58$ (mean $\mathrm{R}_{\text {dev }}{ }^{2}=0.76$ ) using three predictors: HPD, DIS, and TF (Appendix 1, Table A4, Fig. A1). Tapir and woolly monkeys were significantly less depleted in census sectors farther from urban centers. Tapir depletion, for example, remains high at $50 \mathrm{~km}$, and even $100 \mathrm{~km}$, from urban centers (predict $72 \%$ and $56 \%$ sector depletion, respectively), yet falls to just $7 \%$ areal depletion in sectors $300 \mathrm{~km}$ from urban centers (Fig. 5A). Negative interactions for four species show they are significantly less depleted in remote sectors, but this relationship only holds when TF coverage is high.
Fig. 4. Model predictions (solid lines and standard errors in gray) from minimal generalized linear models (GLMs) for hunter-reported faunal depletion distances (solid dots) around 161 rural riverine settlements for selected significant predictors: (A-B) Travel distance from nearest urban center; (C-D) Coverage of unflooded terra firme within $5 \mathrm{~km}$ radius; (E-F) Settlement size (households). Species are: tapir, Tapirus terrestris (A,C), white-lipped peccary, Tayassu pecari (B,D,F), and woolly monkeys, Lagothrix spp. (E). The GLM results for all 10 study species are shown in Appendix 1, Table A3.
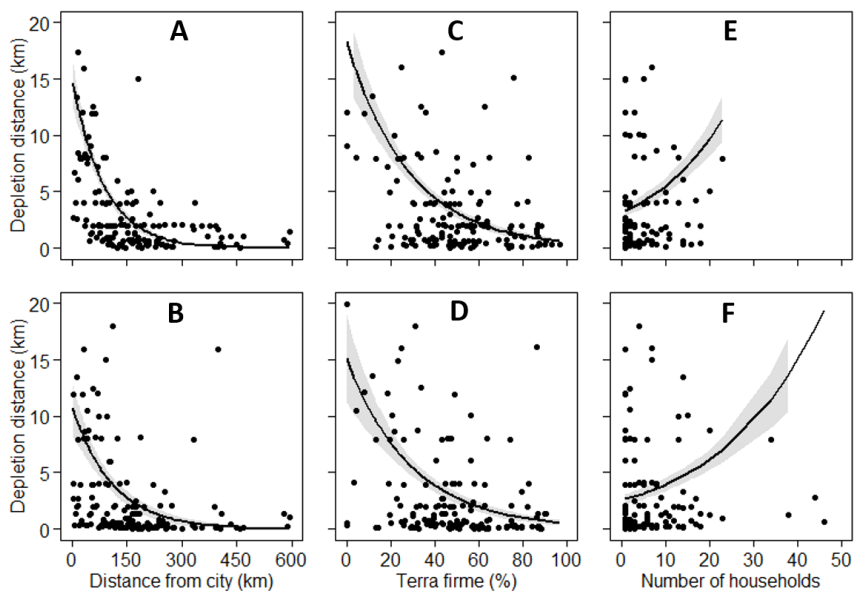

Fig. 5. Model predictions (solid lines, with standard errors in gray) and field estimates (solid dots) for the depletion (absence) of hunted vertebrates within census sectors $(n=41)$ in Amazonas State, Brazil, for three predictors: (A-B) travel distance from nearest urban center; (C-D) coverage of upland terra firme; and (E-F) human population density. Species are: tapir, Tapirus terrestris (A,F); woolly monkeys, Lagothrix spp. (B,D); white-lipped peccary, Tayassu pecari (C,E). Minimal generalized linear model (GLM) results for proportional sector depletion for all 10 study species are shown in Appendix 1, Table A4.
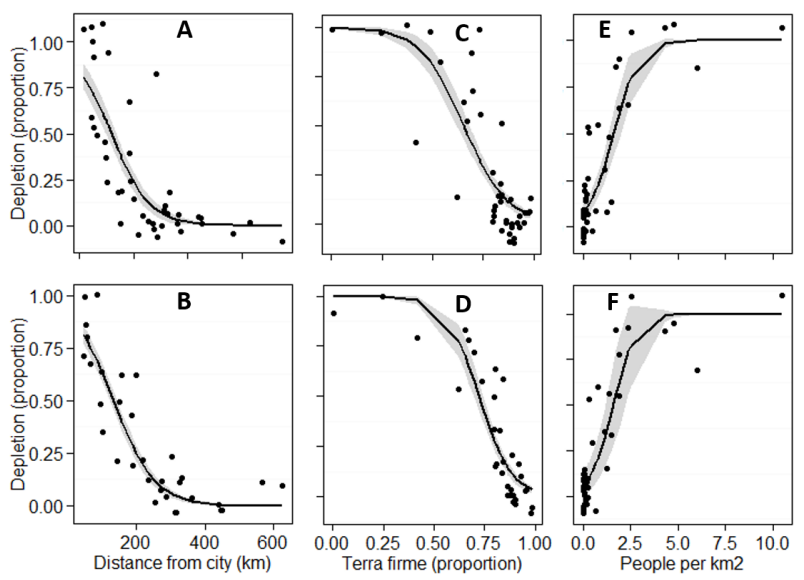
Fig. 6. Predicted depletion levels of large-bodied vertebrates within census sectors in Amazonas State, Brazil, based on speciesspecific predictive models that used human population density, coverage of terra firme upland, and travel distance to the nearest urban center. Species shown are: (A) white-lipped peccary, Tayassu pecari, (B) woolly monkeys, Lagothrix spp., (C) tapir, Tapirus terrestris, and (D) red brocket deer, Mazama americana. Predictive maps for the other six study species are shown in Appendix 1, Fig. A4.

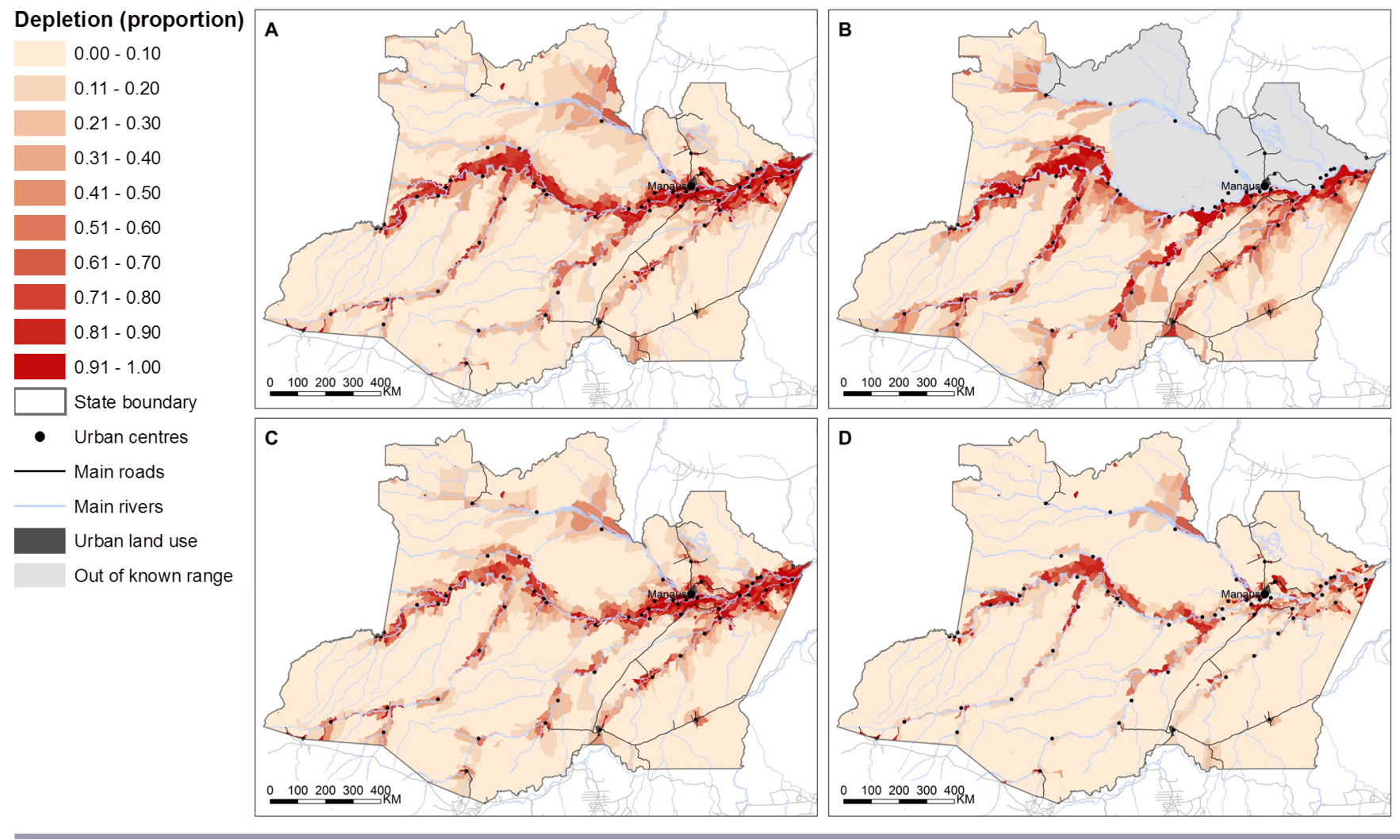

Tapir, white-lipped peccary, spider monkeys, and tortoise were significantly more depleted in sectors with higher HPD and, along with woolly monkeys and saki monkeys, significantly less depleted in areas with high TF. White-lipped peccary, with the strongest HPD effect, is predicted to be depleted from only $10 \%$ of the area within sparsely settled census sectors $\left(0.1\right.$ people $\left.\mathrm{km}^{2}\right)$, rising to $29 \%$ at 1 person $\mathrm{km}^{-2}$, and $89 \%$ depletion at 3 people $\mathrm{km}^{-2}$ (Fig. 5C). Species had varying levels of dependence on TF: woolly and spider monkeys had the strongest effects and saki monkeys the weakest. Woolly monkeys would be depleted from $94 \%$ of a 50:50 TF: várzea landscape, falling to $10 \%$ depletion in a sector with 90\% TF (Fig. 5F). Overall, depletion was lowest in TF-dominated sectors that were either far from urban centers or sparsely settled.

We used predictive models of faunal depletion in census sectors to estimate large-scale patterns of depletion (Fig. 2B). The greatest depletion within Amazonas state is estimated for tortoises, at $39 \%$ of their range within the state. However, considering only the five species with reasonably good model fits $\left(\mathrm{R}^{2} \geq 0.43\right)$ for settlement-scale predictions, total depletion is estimated to be $17 \%$ for woolly monkeys and white-lipped peccary, followed by tapir $(13 \%)$, collared peccary $(11 \%)$, and red brocket deer $(7 \%)$. Heavily depleted census sectors are spatially clustered (Fig. 6). White-lipped peccary, for example, is predicted to be largely absent from a strip approximately $100 \mathrm{~km}$ wide covering both sides of the main Rio Solimões-Amazonas, stretching from west to east (Fig. 6A), because of dense human habitation and limited upland areas of TF forest (Appendix 1, Fig. A1). Woolly monkeys are predicted to be heavily depleted along the main channel, large sections of major tributaries (Rio Juruá, Rio Purús, Rio Madeira), and within $100 \mathrm{~km}$ of urban centers (Fig. 6B). However, within Amazonas state there are also vast areas in which faunal depletion is probably very low. For example, although total woolly monkey depletion is estimated at $203,048 \mathrm{~km}^{2}$, this is mostly caused by partial depletion of census sectors (Fig. 6B, Appendix 1, Fig. A3). Sectors depleted by $\geq 90 \%$ covered only $42,255 \mathrm{~km}^{2}$ ( $4 \%$ of their range), whereas sectors with $<10 \%$ depletion covered $769,240 \mathrm{~km}$ (64\% of range). Lightly depleted areas are mainly restricted to the interfluvial zones between the main second-order tributaries (Fig. 6A-D), which are far from urban centers, sparsely inhabited, and dominated by large areas of TF forest.

\section{DISCUSSION}

Our results demonstrate that local ecological knowledge (LEK) can be combined with quantitative data on human population density, distance from cities, and land form to accurately predict the local depletion of Amazonian forest wildlife. Adept rural hunters could clearly identify the nearest point around their 
settlement at which 10 species of large-bodied vertebrates were recently detected (Flesher and Ley 1996), if locally extant. We also achieved robust estimates of faunal depletion at both the landscape and regional scale, which is vital for evaluating progress against conservation targets yet often infeasible using conventional ecological techniques (Jones 2011). Consequently, our findings confirm that using LEK-based interviews can be effective and efficient for monitoring vulnerable tropical-forest species over large spatial scales (Meijaard et al. 2011, Turvey et al. 2014, Abram et al. 2015). To our knowledge, this is the first study using LEK to make quantitative predictions for the depletion levels of multiple hunted species. We outline the conservation and management implications of our results and consider the potential of this method for monitoring the sustainability of hunting in tropical forests.

Our results represent progress in developing monitoring approaches that can be widely replicated to separate the effects of multiple pressures on threatened species (Meijaard et al. 2011). By conducting interviews at 161 settlements across 7 major Amazonian watersheds, we could separate species-specific drivers of depletion and identify which species were most sensitive to human disturbance. Four species (woolly monkeys, tapir, and both species of peccary) were heavily depleted and had highly predictable responses to both settlement and landscape drivers. Large-bodied species are prone to overexploitation (Peres and Palacios 2007, Levi et al. 2011) because of hunter preference and low intrinsic rates of increase (Bodmer 1995). Worryingly, we estimate this quartet of game species to be absent from $11-17 \%$ of their putative ranges within Amazonas, even though this state retains $98 \%$ of its original forest intact (Instituto Nacional de Pesquisas Espaciais 2013). Heavy depletion along the main navigable rivers is contrasted against low levels of disturbance in the vast interfluvial areas, which are sparsely inhabited and far from urban centers (Fig. 6). This heterogeneity undermines the utility of coarse-scale global analyses (e.g., Grenyer et al. 2006), which assume uniform distribution within species ranges (Hurlbert and Jetz 2007). In fact, broad assumptions of ubiquitous depletion of forest wildlife outside of protected areas (Redford and Sanderson 2000, Terborgh 2000) are rarely tested, and data on depletion is generally lacking (Schwartzman et al. 2000, Jones 2011). Although interviews revealed considerable depletion of curassow and spider monkeys, predictive models of these species (particularly spider monkeys) were less robust, reducing confidence in the likely accuracy of large-scale estimates.

Nine species were less depleted in remote or sparsely populated areas. The effect of city distance, including severe depletion of tapir and white-lipped peccary well over $100 \mathrm{~km}$ from urban centers, suggests that bushmeat consumption in small Amazonian cities has far-reaching impacts on forest wildlife. Parry et al. (2014) found that $79 \%$ of urban households in Amazonian towns consume bushmeat, including both peccaries (each consumed by $19 \%$ of households within the previous 12 months), tapir (15\%), and woolly monkeys (3\%). Faunal depletion near cities, combined with evidence of urban bushmeat consumption (Parry et al. 2014, van Vliet et al. 2014), implies that continued urbanization in forested regions will not necessarily alleviate pressure on threatened species (Wilkie et al. 2011). Moreover, the greater depletion we observed in more densely settled rural areas is consistent with the known impacts of rural subsistence hunting on Amazonian wildlife (Peres 2000, Peres and Palacios 2007). This is also congruent with the much greater reliance, in terms of overall biomass of game meat consumed, on harvest-tolerant species with fast life histories in densely settled areas (Peres 2011). The region's river dwellers now live close to urban centers (Parry et al. 2010), so most rural Amazonians probably live within (and depend upon) relatively empty forests (Redford 1992). In addition to food security concerns, the loss or decline of ecologically important species could lead to altered ecosystem functioning (Stoner et al. 2007, Wright et al. 2007). Finally, we show that in addition to human pressures, landscape features influence the local occupancy of wildlife species. Specifically, hunters generally had to go farther to encounter wildlife in areas dominated by seasonally flooded forest (várzea), which is unsuitable for most large terrestrial vertebrates for half of the year (Haugaasen and Peres 2005).

\section{Limitations}

Further field research is required to validate and refine our depletion predictions (Keane 2013). For instance, the accuracy and precision of estimates could be validated by asking hunters to show researchers the nearest location at which a given species was detected (Flesher and Ley 1996), allowing for georeferencing. Although distance to primary forest only explained the local-scale depletion of two species, the accuracy of large-scale predictions might be improved by including measures of forest cover or land use. However, forest cover is difficult to estimate in floodplain forests and distinguishing older secondary and primary forest requires extensive ground truthing (Grainger 2008). The latter would be problematic because large vertebrates vary in their tolerance of secondary forest (Parry et al. 2007). We may underestimate hunting impacts because we measured only presence-absence, not relative abundance, which can be calibrated with absolute abundance (Moller et al. 2004, Anadón et al. 2009). Nonetheless, obtaining reliable measures of relative abundance requires intensive data collection in a given site (Rist et al. 2008, Parry et al. 2009), contrary to the efficiency of the rapidassessment interviews presented. Finally, direct comparisons between species may be biased by potential differences in their detectability (Yoccoz et al. 2001).

\section{Management implications and future research}

Our methodological approach could provide a cost-effective way to monitor the sustainability of hunting at large spatial scales. For example, policy makers could use human census data, or demographic modelling, to explore the effects of human-fertility transitions or rural-urban migration on hunted wildlife in sustainable-use reserves or indigenous territories. Institutions might choose to invest in field-based interviews either by addressing specific management questions using targeted monitoring of wildlife or by detecting the unknown unknowns using surveillance monitoring (Wintle et al. 2010). Interviews could be adapted to include additional questions for detecting temporal changes in the relative abundance of hunted species (Ziembicki et al. 2013) as well as to map conflicts and threats (Abram et al. 2015). Could measuring detection distances also underpin community-based monitoring by elucidating temporal trends in faunal abundance? A community using this method over several years would be alerted to overhunting and be able to develop and audit management interventions (Jones et al. 2013), 
such as no-take areas or species-specific restrictions (Puertas and Bodmer 2004). Sustainable hunting is an important issue for rural livelihoods and food security so perhaps local motivation for this kind of monitoring would be significant (Singh et al. 2014). However, monitoring is only genuinely participatory if local stakeholders are active and equal participants in decision-making processes, rather than just agents of data collection (Brook and McLachlan 2008, Jones et al. 2013). Greater local involvement also leads to more rapid translation of monitoring results into management action (Danielsen et al. 2010).

\section{CONCLUSION}

Using rapid interviews to assess depletion is an important advance for monitoring the sustainability of hunting in tropical forests. We have developed a cost-effective monitoring technique that uses local ecological knowledge and can be widely replicated, ideal for resource-limited and spatially extensive tropical contexts (Danielsen et al. 2010, Waldron et al. 2013). This is encouraging because the information provided by local resource users on species-specific depletion can be consistent with current scientific knowledge (Gagnon and Berteaux 2009, Turvey et al. 2013, Ziembicki et al. 2013, Beaudreau and Levin 2014). Scaling up our predictions of faunal depletion using census data and geographic variables could provide policy makers with a rare opportunity to audit progress against national conservation targets (Jones 2011). We show that hunting has led to the depletion of threatened species from large areas of their putative ranges, even in the 1.6 million $\mathrm{km}^{2}$ Brazilian State of Amazonas, in which primary forests are still intact. This depletion is caused by bushmeat consumption in rural and urban areas, evidence that the impacts of urban demand ( $\mathrm{Fa}$ et al. 2015) extend to Amazonia. Worryingly, overhunting poses threats to ecosystem functioning (Stoner et al. 2007) as well as human food security (Golden et al. 2011). However, improved management is more likely when local stakeholders are empowered to monitor and comanage their own resources (Brook and McLachlan 2008, Danielsen et al. 2010), highlighting a weakness of rapid surveys. Nevertheless, our findings confirm that local ecological knowledge is an invaluable source of information for monitoring hunted species in data-poor environments.

Responses to this article can be read online at: http://www.ecologyandsociety.org/issues/responses. $\mathrm{php} / 7601$

\section{Acknowledgments:}

We are grateful to the rural Amazonians who shared their knowledge and generously participated in this research. We also thank the Brazilian government for permission to conduct this study (Portaria Ministério No. 908, 04/12/2006). We are grateful to A. Southern and K. Appleton for GIS advice and L. Zanetti, J. Barlow, and H. Griffiths for statistical advice. T.A. Gardner, K. Abernethy, and E. Nichols provided useful comments on earlier versions of this manuscript. We thank two anonymous reviewers for their useful comments. Field research was funded by NERC and the Center for International Forestry Research (CIFOR). Writing time for LP was funded by an ESRC Future Research Leaders Fellowship.
}

\section{LITERATURE CITED}

Abram, N. K., E. Meijaard, J. A. Wells, M. Ancrenaz, A.-S. Pellier, R. K. Runting, D. Gaveau, S. Wich, Nardiyono, A. Tjiu, A. Nurcahyo, and K. Mengersen. 2015. Mapping perceptions of species' threats and population trends to inform conservation efforts: the Bornean orangutan case study. Diversity and Distributions 21:487-499. http://dx.doi.org/10.1111/ddi.12286

Anadón, J. D., A. Giménez, R. Ballestar, and I. Pérez. 2009. Evaluation of local ecological knowledge as a method for collecting extensive data on animal abundance. Conservation Biology 23:617-625. http://dx.doi.org/10.1111/j.1523-1739.2008.01145. $\underline{x}$

Ban, N. C., C. R. Picard, and A. C. J. Vincent. 2009. Comparing and integrating community-based and science-based approaches to prioritizing marine areas for protection. Conservation Biology 23:899-910. http://dx.doi.org/10.1111/j.1523-1739.2009.01185.x

Beaudreau, A. H., and P. S. Levin. 2014. Advancing the use of local ecological knowledge for assessing data-poor species in coastal ecosystems. Ecological Applications 24:244-256. http://dx. doi.org/10.1890/13-0817.1

Berkes, F., and C. Folke, editors. 1998. Linking social and ecological systems: management practices and social brook mechanisms for building resilience. Cambridge University Press, Cambridge, UK.

Berkes, F., J. Colding, and C. Folke. 2000. Rediscovery of traditional ecological knowledge as adaptive management. Ecological Applications 10:1251-1262. http://dx.doi.org/10.1890/1051-0761 (2000)010[1251:ROTEKA]2.0.CO;2

Bodmer, R. E. 1995. Managing Amazonian wildlife: biological correlates of game choice by detribalized hunters. Ecological Applications 5:872-877. http://dx.doi.org/10.2307/2269338

Bodmer, R. E., and J. G. Robinson. 2004. Evaluating the sustainability of hunting in the Neotropics. Pages 299-323 in K. M. Silvius, R. E. Bodmer, and J. M. V. Fragoso, editors. People in nature: wildlife conservation in South and Central America. Columbia University Press, New York, New York, USA.

Brook, R. K., and S. M. McLachlan. 2008. Trends and prospects for local knowledge in ecological and conservation research and monitoring. Biodiversity and Conservation 17:3501-3512. http:// dx.doi.org/10.1007/s10531-008-9445-X

Ceballos, G., and P. R. Ehrlich. 2002. Mammal population losses and the extinction crisis. Science 296:904-907. http://dx.doi. org/10.1126/science. 1069349

Colding, J., and C. Folke. 2001. Social taboos: "invisible" systems of local resource management and biological conservation. Ecological Applications 11:584-600. http://dx.doi.org/10.2307/3060911

Collen, B., J. Loh, S. Whitmee, L. McRae, R. Amin, and J. E. M. Baillie. 2009. Monitoring change in vertebrate abundance: the Living Planet Index. Conservation Biology 23:317-327. http://dx. doi.org/10.1111/j.1523-1739.2008.01117.x

Danielsen, F., N. D. Burgess, and A. Balmford. 2005. Monitoring matters: examining the potential of locally-based approaches. Biodiversity and Conservation 14:2507-2542. http://dx.doi. org/10.1007/s10531-005-8375-0 
Danielsen, F., N. D. Burgess, A. Balmford, P. F. Donald, M. Funder, J. P. G. Jones, P. Alviola, D. S. Balete, T. Blomley, J. Brashares, B. Child, M. Enghoff, J. Fjeldsa, S. Holt, H. Hübertz, A. E. Jensen, P. M. Jensen, J. Massao, M. M. Mendoza, Y. Ngaga, M. K. Poulsen, R. Rueda, M. Sam, T. Skielboe, G. Stuart-Hill, E. Topp-Jørgensen, and D. Yonten. 2009. Local participation in natural resource monitoring: a characterization of approaches. Conservation Biology 23:31-42. http://dx.doi.org/10.1111/ j.1523-1739.2008.01063.x

Danielsen, F., N. D. Burgess, P. M. Jensen, and K. Pirhofer-Walzl. 2010. Environmental monitoring: the scale and speed of implementation varies according to the degree of peoples involvement. Journal of Applied Ecology 47:1166-1168. http://dx. doi.org/10.1111/j.1365-2664.2010.01874.x

Davis, A., and J. R. Wagner. 2003. Who knows? On the importance of identifying "experts" when researching local ecological knowledge. Human Ecology 31:463-489. http://dx.doi.org/10.1023/ A:1025075923297

de Thoisy, B., S. Brosse, and M. A. Dubois. 2008. Assessment of large-vertebrate species richness and relative abundance in Neotropical forest using line-transect censuses: what is the minimal effort required? Biodiversity and Conservation 17:2627-2644. http://dx.doi.org/10.1007/s10531-008-9337-0

ESRI. 2012. ArcGIS 10.1 ESRI, Redlands, California, USA. [online] URL: http://www.esri.com/software/arcgis

Fa, J. E., J. Olivero, M. Á. Farfán, A. L. Márquez, J. Duarte, J. Nackoney, A. Hall, J. Dupain, S. Seymour, P. J. Johnson, D. W. Macdonald, R. Real, and J. M. Vargas. 2015. Correlates of bushmeat in markets and depletion of wildlife. Conservation Biology 29:805-815. http://dx.doi.org/10.1111/cobi.12441

Ferguson, M. A. D., R. G. Williamson, and F. Messier. 1998. Inuit knowledge of long-term changes in a population of Arctic tundra caribou. Arctic 51:201-219. http://dx.doi.org/10.14430/arctic1062

Flesher, K., and E. Ley. 1996. A frontier model for landscape ecology: the tapir in Honduras. Environmental and Ecological Statistics 3:119-125. http://dx.doi.org/10.1007/BF02427857

Gagnon, C. A., and D. Berteaux. 2009. Integrating traditional ecological knowledge and ecological science: a question of scale. Ecology and Society 14(2): 19. [online] URL: http://www. ecologyandsociety.org/vol14/iss2/art19/

Gardner, T. A., J. Barlow, I. S. Araujo, T. C. Ávila-Pires, A. B. Bonaldo, J. E. Costa, M. C. Esposito, L. V. Ferreira, J. Hawes, M. I. M. Hernandez, M. S. Hoogmoed, R. N. Leite, N. F. Lo-ManHung, J. R. Malcolm, M. B. Martins, L. A. M. Mestre, R. Miranda-Santos, W. L. Overal, L. Parry, S. L. Peters, M. A. Ribeiro-Junior, M. N. F. Da Silva, C. Da Silva Motta, and C. A. Peres. 2008. The cost-effectiveness of biodiversity surveys in tropical forests. Ecology Letters 11:139-150. http://dx.doi. org/10.1111/j.1461-0248.2007.01133.x

Gentleman, R., and R. Ihaka. 2014. R. Version 3.1.0. Free Software Foundation, Boston, Massachusetts, USA. http://www. r-project.org

Golden, C. D., L. C. H. Fernald, J. S. Brashares, B. J. R. Rasolofoniaina, and C. Kremen. 2011. Benefits of wildlife consumption to child nutrition in a biodiversity hotspot. Proceedings of the National Academy of Sciences 108:19653-19656. http://dx.doi.org/10.1073/pnas.1112586108

Graham, M. H. 2003. Confronting multicollinearity in ecological multiple regression. Ecology 84:2809-2815. http://dx.doi. org/10.1890/02-3114

Grainger, A. 2008. Difficulties in tracking the long-term global trend in tropical forest area. Proceedings of the National Academy of Sciences 105:818-823. http://dx.doi.org/10.1073/pnas.0703015105

Grant, S., and F. Berkes. 2007. Fisher knowledge as expert system: a case from the longline fishery of Grenada, the Eastern Caribbean. Fisheries Research 84:162-170. http://dx.doi. org/10.1016/j.fishres.2006.10.012

Grenyer, R., C. D. L. Orme, S. F. Jackson, G. H. Thomas, R. G. Davies, T. J. Davies, K. E. Jones, V. A. Olson, R. S. Ridgely, P. C. Rasmussen, T.-S. Ding, P. M. Bennett, T. M. Blackburn, K. J. Gaston, J. L. Gittleman, and I. P. F. Owens. 2006. Global distribution and conservation of rare and threatened vertebrates. Nature 444:93-96. http://dx.doi.org/10.1038/nature05237

Haugaasen, T., and C. A. Peres. 2005. Mammal assemblage structure in Amazonian flooded and unflooded forests. Journal of Tropical Ecology 21:133-145. http://dx.doi.org/10.1017/ $\underline{\mathrm{S} 026646740400207 \mathrm{X}}$

Hess, L. L., J. Melack, E. M. L. M. Novo, C. C. F. Barbosa, and M. Gastil. 2003. Dual-season mapping of wetland inundation and vegetation for the central Amazon basin. Remote Sensing of Environment 87:404-428. http://dx.doi.org/10.1016/j.rse.2003.04.001

Huntington, H. P. 2000. Using traditional ecological knowledge in science: methods and applications. Ecological Applications 10:1270-1274. http://dx.doi.org/10.1890/1051-0761(2000)010[1270: UTEKIS]2.0.CO;2

Hurlbert, A. H., and W. Jetz. 2007. Species richness, hotspots, and the scale dependence of range maps in ecology and conservation. Proceedings of the National Academy of Sciences 104:13384-13389. http://dx.doi.org/10.1073/pnas.0704469104

Instituto Brasileiro de Geografia e Estatistica (IBGE). 2007. Contagem populacional de 2007. Instituto Brasileiro de Geografia e Estatisticam, Rio de Janeiro, Brazil.

Instituto Nacional de Pesquisas Espaciais. 2013. Projeto PRODES: monitoramento da floresta amazônica brasileira por satélite. Instituto Nacional de Pesquisas Espaciais, Sao José dos Campos, Brazil.

Jenkins, M., R. E. Green, and J. Madden. 2003. The challenge of measuring global change in wild nature: are things getting better or worse? Conservation Biology 17:20-23. http://dx.doi. org/10.1046/j.1523-1739.2003.01719.x

Jerozolimski, A., and C. A. Peres. 2003. Bringing home the biggest bacon: a cross-site analysis of the structure of hunter-kill profiles in Neotropical forests. Biological Conservation 111:415-425. http://dx.doi.org/10.1016/S0006-3207(02)00310-5

Jick, T. D. 1979. Mixing qualitative and quantitative methods: triangulation in action. Administrative Science Quarterly 24:602-611. http://dx.doi.org/10.2307/2392366 
Jones, J. P. G. 2011. Monitoring species abundance and distribution at the landscape scale. Journal of Applied Ecology 48:9-13. http://dx.doi.org/10.1111/j.1365-2664.2010.01917.x

Jones, J. P. G., G. P. Asner, S. H. M. Butchart, and K. U. Karanth. 2013. The 'why', 'what' and 'how' of monitoring for conservation. Pages 327-343 in D. W. Macdonald and K. J. Willis, editors. Key topics in conservation biology 2. John Wiley and Sons, Hoboken, New Jersey, USA. http://dx.doi.org/10.1002/9781118520178. $\underline{\operatorname{ch} 18}$

Keane, A. 2013. Unusual data in conservation science: searching for validation. Animal Conservation 16:604-605. http://dx.doi. org/10.1111/acv.12091

Levi, T., G. H. Shepard, Jr., J. Ohl-Schacherer, C. A. Peres, and D. W. Yu. 2009. Modelling the long-term sustainability of indigenous hunting in Manu National Park, Peru: landscapescale management implications for Amazonia. Journal of Applied Ecology 46:804-814. http://dx.doi.org/10.1111/j.1365-2664.2009.01661. $\underline{\mathrm{X}}$

Levi, T., G. H. Shepard, Jr., J. Ohl-Schacherer, C. C. Wilmers, C. A. Peres, and D. W. Yu. 2011. Spatial tools for modeling the sustainability of subsistence hunting in tropical forests. Ecological Applications 21:1802-1818. http://dx.doi.org/10.1890/10-0375.1

Lindenmayer, D. B., and G. E. Likens. 2009. Adaptive monitoring: a new paradigm for long-term research and monitoring. Trends in Ecology and Evolution 24:482-486. http://dx.doi.org/10.1016/j. tree.2009.03.005

Luzar, J. B., K. M. Silvius, H. Overman, S. T. Giery, J. M. Read, and J. M. V. Fragoso. 2011. Large-scale environmental monitoring by Indigenous peoples. BioScience 61:771-781. http://dx.doi. org/10.1525/bio.2011.61.10.7

Meijaard, E., K. Mengersen, D. Buchori, A. Nurcahyo, M. Ancrenaz, S. Wich, S. S. U. Atmoko, A. Tjiu, D. Prasetyo, Nardiyono, Y. Hadiprakarsa, L. Christy, J. Wells, G. Albar, and A. J. Marshall. 2011. Why don't we ask? A complementary method for assessing the status of great apes. PLOS ONE 6: e18008. http://dx.doi.org/10.1371/journal.pone.0018008

Milner-Gulland, E. J., E. L. Bennett, and SCB 2002 Annual Meeting Wild Meat Group. 2003. Wild meat: the bigger picture. Trends in Ecology and Evolution 18:351-357. http://dx.doi. org/10.1016/S0169-5347(03)00123-X

Moller, H., F. Berkes, P. O. Lyver, and M. Kislalioglu. 2004. Combining science and traditional ecological knowledge: monitoring populations for co-management. Ecology and Society 9(3): 2. [online] URL: http://www.ecologyandsociety.org/vol9/ iss $3 / \operatorname{art} 21$

Munari, D. P., C. Keller, and E. M. Venticinque. 2011. An evaluation of field techniques for monitoring terrestrial mammal populations in Amazonia. Mammalian Biology 76:401-408. http://dx.doi.org/10.1016/j.mambio.2011.02.007

Parry, L., J. Barlow, and H. Pereira. 2014. Wildlife harvest and consumption in Amazonia's urbanized wilderness. Conservation Letters 7:565-574. http://dx.doi.org/10.1111/conl.12151

Parry, L., J. Barlow, and C. A. Peres. 2007. Large-vertebrate assemblages of primary and secondary forests in the Brazilian
Amazon. Journal of Tropical Ecology 23:653-662. http://dx.doi. org/10.1017/S0266467407004506

Parry, L. T. W. 2009. Spatial changes in Amazonian non-timber resource use. Dissertation. School of Environmental Sciences, University of East Anglia. Norwich, UK.

Parry, L., J. Barlow, and C. A. Peres. 2009. Allocation of hunting effort by Amazonian smallholders: implications for conserving wildlife in mixed-use landscapes. Biological Conservation 142:1777-1786. http://dx.doi.org/10.1016/j.biocon.2009.03.018

Parry, L., C. A. Peres, B. Day, and S. Amaral. 2010. Rural-urban migration brings conservation threats and opportunities to Amazonian watersheds. Conservation Letters 3:251-259. http:// dx.doi.org/10.1111/j.1755-263X.2010.00106.x

Peres, C. A. 2000. Evaluating the impact and sustainability of subsistence hunting at multiple Amazonian forest sites. Pages 31-56 in J. G. Robinson, and E. L. Bennett, editors. Hunting for sustainability in tropical forests. Columbia University Press, New York, New York, USA.

Peres, C. A. 2011. Conservation in sustainable-use tropical forest reserves. Conservation Biology 25:1124-1129. http://dx.doi. org/10.1111/j.1523-1739.2011.01770.x

Peres, C. A., J. Barlow, and W. F. Laurance. 2006. Detecting anthropogenic disturbance in tropical forests. Trends in Ecology and Evolution 21:227-229. http://dx.doi.org/10.1016/j.tree.2006.03.007

Peres, C. A., and E. Palacios. 2007. Basin-wide effects of game harvest on vertebrate population densities in Amazonian forests: implications for animal-mediated seed dispersal. Biotropica 39:304-315. http://dx.doi.org/10.1111/j.1744-7429.2007.00272.x

Plumptre, A. J. 2000. Monitoring mammal populations with line transect techniques in African forests. Journal of Applied Ecology 37:356-368. http://dx.doi.org/10.1046/j.1365-2664.2000.00499.x

Puertas, P. E., and R. E. Bodmer. 2004. Hunting effort as a tool for community-based wildlife management in Amazonia. Pages 123-138 in K. M. Silvius, R. E. Bodmer, and J. M. V. Fragoso, editors. People in nature: wildlife conservation in South and Central America. Columbia University Press, New York, New York, USA.

Redford, K. H. 1992. The empty forest. Bioscience 42:412-422. http://dx.doi.org/10.2307/1311860

Redford, K. H., and S. E. Sanderson. 2000. Extracting humans from nature. Conservation Biology 14:1362-1364. http://dx.doi. org/10.1046/j.1523-1739.2000.00135.x

Rist, J., M. Rowcliffe, G. Cowlishaw, and E. J. Milner-Gulland. 2008. Evaluating measures of hunting effort in a bushmeat system. Biological Conservation 141:2086-2099. http://dx.doi. org/10.1016/j.biocon.2008.06.005

Schwartzman, S., A. Moreira, and D. Nepstad. 2000. Rethinking tropical forest conservation: perils in parks. Conservation Biology 14:1351-1357. http://dx.doi.org/10.1046/j.1523-1739.2000.99329. $\underline{\mathrm{X}}$

Silvertown, J. 2009. A new dawn for citizen science. Trends in Ecology and Evolution 24:467-471. http://dx.doi.org/10.1016/j. tree.2009.03.017 
Singh, N. J., K. Danell, L. Edenius, and G. Ericsson. 2014. Tackling the motivation to monitor: success and sustainability of a participatory monitoring program. Ecology and Society 19(4): 7. http://dx.doi.org/10.5751/es-06665-190407

Sirén, A., P. Hambäck, and E. Machoa. 2004. Including spatial heterogeneity and animal dispersal when evaluating hunting: a model analysis and an empirical assessment in an Amazonian community. Conservation Biology 18:1315-1329. http://dx.doi. org/10.1111/j.1523-1739.2004.00024.X

Stoner, K. E., P. Riba-Hernández, K. Vulinec, and J. E. Lambert. 2007. The role of mammals in creating and modifying seedshadows in tropical forests and some possible consequences of their elimination. Biotropica 39:316-327. http://dx.doi. org/10.1111/j.1744-7429.2007.00292.x

Terborgh, J. 2000. The fate of tropical forests: a matter of stewardship. Conservation Biology 14:1358-1361. http://dx.doi. org/10.1046/j.1523-1739.2000.00136.X

Turvey, S. T., C. L. Risley, J. E. Moore, L. A. Barrett, H. Yujiang, Z. Xiujiang, Z. Kaiya, and W. Ding. 2013. Can local ecological knowledge be used to assess status and extinction drivers in a threatened freshwater cetacean? Biological Conservation 157:352-360.

Turvey, S. T., C. T. Trung, V. D. Quyet, H. V. Nhu, D. V. Thoai, V. C. A. Tuan, D. T. Hoa, K. Kacha, T. Sysomphone, S. Wallate, C. T. T. Hai, N. V. Thanh, and N. M. Wilkinson. 2014. Interviewbased sighting histories can inform regional conservation prioritization for highly threatened cryptic species. Journal of Applied Ecology 52:422-433. http://dx.doi.org/10.1111/1365-2664.12382

van Vliet, N., M. P. Quiceno-Mesa, D. Cruz-Antia, L. J. N. de Aquino, J. Moreno, and R. Nasi 2014. The uncovered volumes of bushmeat commercialized in the Amazonian trifrontier between Colombia, Peru and Brazil. Ethnobiology and Conservation 3 (7):1-11

Waldron, A., A. O. Mooers, D. C. Miller, N. Nibbelink, D. Redding, T. S. Kuhn, J. T. Roberts, and J. L. Gittleman. 2013. Targeting global conservation funding to limit immediate biodiversity declines. Proceedings of the National Academy of Sciences 110:12144-12148. http://dx.doi.org/10.1073/pnas.1221370110

Wilkie, D. S., E. L. Bennett, C. A. Peres, and A. A. Cunningham. 2011. The empty forest revisited. Annals of the New York Academy of Sciences 1223:120-128. http://dx.doi.org/10.1111/ j.1749-6632.2010.05908.x

Wintle, B. A., M. C. Runge, and S. A. Bekessy. 2010. Allocating monitoring effort in the face of unknown unknowns. Ecology Letters 13:1325-1337. http://dx.doi.org/10.1111/j.1461-0248.2010.01514. $\underline{\mathrm{x}}$

Wright, S. J., K. E. Stoner, N. Beckman, R. T. Corlett, R. Dirzo, H. C. Muller-Landau, G. Nuñez-Iturri, C. A. Peres, and B. C. Wang. 2007. The plight of large animals in tropical forests and the consequences for plant regeneration. Biotropica 39:289-291. http://dx.doi.org/10.1111/j.1744-7429.2007.00293.x
Yoccoz, N. G., J. D. Nichols, and T. Boulinier. 2001. Monitoring of biological diversity in space and time. Trends in Ecology and Evolution 16:446-453. http://dx.doi.org/10.1016/S0169-5347(01) 02205-4

Ziembicki, M. R., J. C. Z. Woinarski, and B. Mackey. 2013. Evaluating the status of species using Indigenous knowledge: novel evidence for major native mammal declines in northern Australia. Biological Conservation 157:78-92. http://dx.doi. org/10.1016/j.biocon.2012.07.004 


\title{
Appendix 1.
}

\section{Evaluating the use of local ecological knowledge to monitor hunted tropical-forest wildlife over large spatial scales}

\author{
Luke Parry and Carlos A. Peres
}

\author{
METHODS
}

\section{Assessing depletion}

On arriving in settlements we first sought out the elected community leader or, when not available, other informal leaders such as life-long residents, locally-born school teacher, etc. We conducted separate interviews at the level of settlement and household concerning hunting as well as the drivers of settlement growth and rural-to-urban migration (see Parry et al. 2010a,b). We only conducted interviews after we had explained the objectives of our research, giving full assurance of confidentiality, and then obtaining verbal consent to participate. The vast majority of interviewees were caboclos, the mixed descendants of Amerindians, European colonists and African slaves. Amazonas State's rural population of 735,000 people (IBGE 2007) includes indigenous peoples, caboclos and more recent colonists from other regions of the country. Interviews lasted around 1 hour, in total. When estimating depletion distances based on travel time, we discounted rest time if the location mentioned by hunters was distant. When an animal was detected close to a settlement, hunters pointed to a landmark (such as a tree) and we visually estimated a distance. Using this method we identified areas wholly depleted of a given species, which can be distinguished from the use of relative depletion when a species may be at reduced abundance, though still present.

\section{Explanatory variables}

Human population density was derived from the estimated number of people living within a $5 \mathrm{~km}$ radius of settlements. This population data was calculated from our own field surveys of settlement size and location with additional settlement data (on size and location) from the Brazilian Federal Epidemiological Vigilance database for malaria (SIVEP-MALÁRIA), high resolution images (IKONOS imagery) from Google Earth (where available), and municipal health secretariat databases. When additional settlement data only provided households, we assumed a mean of 5 persons per household (SIVEP MALARIA 2007). Settlement growth was the change in number of households between 1991 and 2007 and was established during interviews. Interviewees informed us of the approximate age of their settlement. We calculated the travel distance from each riverine settlement to its local urban center using the Network Analysis extension in ArcGIS 10.1 (ESRI, Redlands, California; see Parry et al. 2010a). Distance to primary forest was estimated based on the reported walking time from the center of the settlement, assuming a mean travel velocity on foot of 4 $\mathrm{km} / \mathrm{hr}$. We calculated the percentage of unflooded upland terra firme (as opposed to floodplain várzea) around each settlement (within a $5 \mathrm{~km}$ radial buffer) using a basin-wide raster image reflecting inundation at high water levels (Hess 2003). We did this due to the known differences in abundance of some game species between these forest habitat types (Haugaasen \& Peres 2005).

\section{Accuracy of census sector population data}


There was a highly significant relationship between the 2007 census data collected by IBGE and our own 2007 field data obtained along the surveyed rivers for those census sectors that were entirely surveyed (Fig. A2). Accuracy appeared to be maintained even in remote areas as there was no significant correlation between fluvial distance from the town within a given sector and the percentage difference between the two population density estimates (Pearson correlation: $\mathrm{R}^{2}=0.207, \mathrm{n}=52, \mathrm{p}=0.141$ ).

\section{Hierarchical portioning}

To minimize the constraints of multicollinearity amongst predictors (Table A2), we used hierarchical partitioning (Chevan \& Sutherland 1991) to examine the independent effects of the settlement and landscape variables on depletion distances. Hierarchical partitioning is useful for exploratory analysis and identifying variables likely to be important in regression (e.g. Radford \& Bennett 2007). All possible model combinations are considered in order to partition a measure of association into a variable-specific (independent) component and a joint component that is due to the co-action of two or more variables (MacNally 2000). Patterns of depletion were modelled using quasi-poisson errors and a goodness of fit based on r-square. The significance of independent effects was calculated using a randomization test with 100 iterations (MacNally 2002). These tests were implemented using the hier.part package in R (Walsh \& MacNally 2003). Hierarchical partitioning only partitions the variance explained by selected predictor variables, so we also calculated a measure of overall model fit for the depletion of each species, based on the $\mathrm{R}^{2}$-values of a Generalized Additive Model (GAM). We fitted GAMs using the $m g c v$ package (Wood 2006), as they allow for non-linear trends in responses. We specified a quasi-poisson error and a log link function.

\section{Predicting depletion at settlement and census sector-scales}

During model fitting we used manual stepwise removal of the least significant interaction or variable one at a time, until only significant predictors remained. Quasi-poisson error distributions were specified. Where a given species was never observed around a visited settlement, we estimated a minimum depletion of $12.5 \mathrm{~km}$, the maximum inland distance from a settlement that we estimate hunters to travel. On this basis we also capped very large depletion estimates at $12.5 \mathrm{~km}$ as larger buffers overlapped proximate locations around which the presence of a species had been reported during interviews. We then combined the revised buffers of reported depletion and predicted depletion (visited and unvisited settlements) to calculate the total proportional depletion zones for all species within visited census sectors. For census sector depletion models, we specified a quasi-binomial error distribution because values of the dependent variable were bound between 0 and 1 . 


\section{LITERATURE CITED}

Chevan, A., and M. Sutherland. 1991. Hierarchical partitioning. The American Statistician 45:90-96.

Haugaasen, T., and C. A. Peres. 2005. Mammal assemblage structure in Amazonian flooded and unflooded forests. Journal of Tropical Ecology 21:133-145.

Hess, L. L., J. Melack, E. M. L. M. Novo, C. C. F. Barbosa, and M. Gastil. 2003. Dualseason mapping of wetland inundation and vegetation for the central Amazon basin. Remote Sensing of Environment 87:404-428.

Instituto Brasileiro de Geografía e Estatística (IBGE) 2007. Contagem populacional de 2007.

MacNally, R. 2000. Regression and model-building in conservation biology, biogeography and ecology: The distinction between - and reconciliation of - 'predictive' and 'explanatory' models. Biodiversity and Conservation 9:655-671.

MacNally, R. 2002. Multiple regression and inference in ecology and conservation biology: further comments on identifying important predictor variables. Biodiversity and Conservation 11:1397-1401.

Parry, L., C. A. Peres, B. Day, and S. Amaral. 2010a. Rural-urban migration brings conservation threats and opportunities to Amazonian watersheds. Conservation Letters $3: 251-259$.

Parry, L., B. Day, S. Amaral, and C. A. Peres. 2010b. Drivers of rural exodus from Amazonian headwaters. Population \& Environment 32:137-176.

Radford, J. Q., and A. F. Bennett. 2007. The relative importance of landscape properties for woodland birds in agricultural environments. Journal of Applied Ecology 44:737747.

Sistema de Informacao de Vigilancia Epidemilogico Malaria (SIVEP MALARIA) (2007). http://www.saude.gov.br/sivep_malaria, accessed 1 January 2009.

Walsh, C., and R. MacNally. 2003. Hierarchical partitioning. R Project for Statistical Computing. http:cran.r-project.org/.

Wood, S. N. 2006. Generalized additive models: an introduction with R. Chapman and Hall. 
Table A1. Large vertebrate species for which the depletion zone (distance to nearest direct or indirect encounter within 12 months) was assessed using interviews with rural hunters in Amazonas State, Brazil. The known geographic range of the study species is indicated in relation to the rivers surveyed (taken from natureserve.org and iucnredlist.org). River numbers refer to those shown in a map of the study region (Fig. 1A).

\begin{tabular}{|c|c|c|c|}
\hline Species & & $\begin{array}{l}\text { IUCN threat } \\
\text { status }\end{array}$ & Rivers \\
\hline \multicolumn{4}{|l|}{ Primates } \\
\hline \multirow[t]{2}{*}{ Spider monkeys } & Ateles belzebuth (É. Geoffroy, 1806) & Endangered & 1 \\
\hline & A. chamek (Humboldt, 1812) & Endangered & $3-7$ \\
\hline \multirow[t]{3}{*}{ Woolly monkeys } & Lagothrix cana (Humboldt, 1812) & Endangered & $2-7$ \\
\hline & L. poeppigii (Schinz, 1844) & Vulnerable & spatial model only \\
\hline & L. lagothricha (Humboldt, 1812) & Vulnerable & spatial model only \\
\hline \multirow[t]{2}{*}{ Saki monkeys } & Pithecia irrorata (Gray, 1842) & Least concern & $2-3,5-8$ \\
\hline & P. albicans (Gray, 1860) & Vulnerable & $3-4$ \\
\hline Capuchin & Cebus apella (L., 1758) & Least concern & $1-7$ \\
\hline \multicolumn{4}{|l|}{ Ungulates } \\
\hline South American tapir & Tapirus terrestris (L., 1758) & Vulnerable & $1-7$ \\
\hline White-lipped peccary & Tayassu pecari (Link, 1795) & Vulnerable & $1-7$ \\
\hline Collared peccary & Pecari tajacu (L., 1758) & Least concern & $1-7$ \\
\hline Red brocket deer & $\begin{array}{l}\text { Mazama americana } \\
\text { (Erxleben, 1777) }\end{array}$ & Data deficient & $1-7$ \\
\hline \multicolumn{4}{|l|}{ Birds } \\
\hline \multirow[t]{4}{*}{ Curassow } & Mitu tuberosum (Spix, 1825) & Least concern & $2-7$ \\
\hline & Mitu tomentosum (Spix, 1825) & Near threatened & 1 \\
\hline & Crax globulosa (Spix, 1825) & Endangered & possibly $3-7$ \\
\hline & Crax alector (L., 1766) & Vulnerable & 1 \\
\hline \multicolumn{4}{|l|}{ Reptiles } \\
\hline Tortoises & Chelonoidis denticulata (L. 1766) & Vulnerable & $1-7 ?$ \\
\hline
\end{tabular}


Table A2. Correlation matrix of settlement-scale predictors of depletion of hunted species, with correlation coefficients $\left(\mathrm{r}_{\mathrm{s}}\right)$ shown in bottom left, and P-values in top right. Sample sizes are shown in parentheses beneath coefficients.

\begin{tabular}{|c|c|c|c|c|c|c|c|}
\hline & $\begin{array}{l}\text { No. } \\
\text { household } \\
\text { s }\end{array}$ & $\begin{array}{c}\text { City } \\
\text { distance } \\
(\mathrm{km})\end{array}$ & $\begin{array}{c}\text { Populatio } \\
\mathrm{n} \text { density } \\
\left(\mathrm{km}^{-2}\right)\end{array}$ & $\begin{array}{c}\% \\
\text { unflooded }\end{array}$ & $\begin{array}{c}\text { Primary } \\
\text { forest } \\
\text { distance } \\
(\mathrm{km}) \\
\end{array}$ & $\begin{array}{l}\text { Settlemen } \\
\text { t age } \\
\text { (years) }\end{array}$ & $\begin{array}{l}\text { Settlemen } \\
\text { t growth } \\
\text { (no. hh) }\end{array}$ \\
\hline No. households & & 0.007 & 0.362 & 0.127 & 0.223 & 0.001 & 0.000 \\
\hline City distance $(\mathrm{km})$ & $\begin{array}{c}-0.211 \\
(161)\end{array}$ & & 0.026 & 0.000 & 0.000 & 0.000 & 0.085 \\
\hline $\begin{array}{l}\text { Population density } \\
\left(\mathrm{km}^{-2}\right)\end{array}$ & $\begin{array}{l}0.720 \\
(161)\end{array}$ & $\begin{array}{l}-0.175 \\
(161)\end{array}$ & & 0.140 & 0.078 & 0.945 & 0.916 \\
\hline$\%$ unflooded & $\begin{array}{c}-0.121 \\
(161)\end{array}$ & $\begin{array}{l}0.721 \\
(161)\end{array}$ & $\begin{array}{l}-0.117 \\
(161)\end{array}$ & & 0.000 & 0.001 & 0.496 \\
\hline $\begin{array}{l}\text { Primary forest } \\
\text { distance }(\mathrm{km})\end{array}$ & $\begin{array}{l}0.102 \\
(144)\end{array}$ & $\begin{array}{l}-0.332 \\
(144)\end{array}$ & $\begin{array}{l}0.147 \\
(144)\end{array}$ & $\begin{array}{l}-0.438 \\
(144)\end{array}$ & & 0.010 & 0.443 \\
\hline $\begin{array}{l}\text { Settlement age } \\
\text { (years) }\end{array}$ & $\begin{array}{l}0.264 \\
(159)\end{array}$ & $\begin{array}{l}-0.305 \\
(159)\end{array}$ & $\begin{array}{l}0.006 \\
(159)\end{array}$ & $\begin{array}{l}-0.253 \\
(159)\end{array}$ & $\begin{array}{l}0.280 \\
(142)\end{array}$ & & 0.073 \\
\hline $\begin{array}{l}\text { Settlement growth } \\
\text { (no. households) }\end{array}$ & $\begin{array}{l}0.931 \\
(158)\end{array}$ & $\begin{array}{l}-0.137 \\
(158)\end{array}$ & $\begin{array}{l}-0.008 \\
(158)\end{array}$ & $\begin{array}{l}0.055 \\
(158)\end{array}$ & $\begin{array}{l}0.065 \\
(141)\end{array}$ & $\begin{array}{l}0.144 \\
(156)\end{array}$ & \\
\hline
\end{tabular}


Table A3. Results of minimal Generalized Linear Models of settlement-scale faunal depletion distances. These results were used to predict depletion distances around nonvisited communities along seven rivers in Amazonas State, Brazil. A quasi-poisson error structure was specified. Significance levels refer to: $p<0.1(.) ; p<0.05\left(^{*}\right) ; p<0.01(* *) ; p$ $<0.001(* * *)$.

\begin{tabular}{|c|c|c|c|c|}
\hline Variables & Coefficient & $\mathrm{t}$ & $\mathrm{p}$ & Significance \\
\hline \multicolumn{5}{|l|}{ Tapirus terrestris } \\
\hline (Intercept) & 3.263 & 17.240 & $<2 \mathrm{e}-16$ & $* * *$ \\
\hline settlement size (no. households) & 0.034 & 4.199 & $4.54 \mathrm{e}-05$ & $* * *$ \\
\hline city distance & -0.023 & -8.320 & $4.66 \mathrm{e}-14$ & $* * *$ \\
\hline$\%$ unflooded & -0.016 & -3.391 & 0.0009 & $* * *$ \\
\hline settlement size:\% unflooded & -0.0009 & -4.048 & $8.21 \mathrm{e}-05$ & $* * *$ \\
\hline city distance: $\%$ unflooded & 0.0002 & 6.737 & $3.14 \mathrm{e}-10$ & $* * *$ \\
\hline \multicolumn{5}{|l|}{ Null deviance $=1262.8(157 \mathrm{df})$} \\
\hline Residual deviance $=399.6(152 \mathrm{df})$ & & $\mathrm{R}^{2}=0.68$ & & \\
\hline \multicolumn{5}{|l|}{ Tayassu pecari } \\
\hline (Intercept) & 3.045 & 10.292 & $<2 \mathrm{e}-16$ & $* * *$ \\
\hline settlement size & 0.0214 & 1.954 & 0.052713 & . \\
\hline city distance & -0.015 & -3.411 & 0.000850 & $* * *$ \\
\hline population density & -0.028 & -2.387 & 0.018324 & $*$ \\
\hline$\%$ unflooded & -0.033 & -4.107 & $6.84 \mathrm{e}-05$ & $* * *$ \\
\hline settlement size: city distance & -0.0008 & -2.520 & 0.012867 & $*$ \\
\hline city distance: population density & 0.005 & 2.436 & 0.016122 & $*$ \\
\hline city distance: $\%$ unflooded & 0.0002 & 3.575 & 0.000484 & $* * *$ \\
\hline population density: \% unflooded & 0.0003 & 1.751 & 0.082171 & . \\
\hline \multicolumn{5}{|l|}{ Null deviance $=1304.39(146 \mathrm{df})$} \\
\hline Residual deviance $=653.9(138 \mathrm{df})$ & & $\mathrm{R}^{2}=0.50$ & & \\
\hline \multicolumn{5}{|l|}{ Pecari tajacu } \\
\hline (Intercept) & 2.691 & 5.650 & $7.49 \mathrm{e}-08$ & $* * *$ \\
\hline city distance & -0.017 & -2.524 & 0.01260 & $*$ \\
\hline population density & 0.006 & 2.376 & 0.01874 & $*$ \\
\hline$\%$ unflooded & -0.027 & -2.306 & 0.02244 & $*$ \\
\hline city distance: \% unflooded & 0.0002 & 2.698 & 0.00776 & $* *$ \\
\hline \multicolumn{5}{|l|}{ Null deviance $=1132.6(159 \mathrm{df})$} \\
\hline Residual deviance $=644.4(155 \mathrm{df})$ & & $\mathrm{R}^{2}=0.43$ & & \\
\hline \multicolumn{5}{|l|}{ Mazama americana } \\
\hline (Intercept) & 2.206 & 7.586 & $2.99 \mathrm{e}-12$ & $* * *$ \\
\hline city distance & -0.010 & -2.464 & 0.014841 & $*$ \\
\hline population density & 0.010 & 7.094 & $4.54 \mathrm{e}-11$ & $* * *$ \\
\hline$\%$ unflooded & -0.053 & -6.342 & $2.43 \mathrm{e}-09$ & $* * *$ \\
\hline city distance: \% unflooded & 0.0002 & 3.799 & 0.000209 & $* * *$ \\
\hline \multicolumn{5}{|l|}{ Null deviance $=797.9(157 \mathrm{df})$} \\
\hline Residual deviance $=266.3$ (153 df) & & $\mathrm{R}^{2}=0.67$ & & \\
\hline \multicolumn{5}{|l|}{ Crax/Mitu spp. } \\
\hline (Intercept) & 1.095 & 6.020 & $1.26 \mathrm{e}-08$ & $* * *$ \\
\hline settlement size & 0.007 & 4.605 & $8.66 \mathrm{e}-06$ & $* * *$ \\
\hline city distance & -0.005 & -4.161 & $5.29 \mathrm{e}-05$ & $* * *$ \\
\hline
\end{tabular}


Null deviance $=464.4(154 \mathrm{df})$

Residual deviance $=323.1(152 \mathrm{df})$

$$
\mathrm{R}^{2}=0.30
$$

Chelonoidis spp.

(Intercept)

settlement size

1.393

2.869

0.00497

0.058

2.622

0.01001

$-2.159$

0.03309

0.028

$\%$ unflooded

2.601

0.01061

settlement size: $\%$ unflooded

$-2.600$

0.01063

Null deviance $=1855.8(111 \mathrm{df})$

Residual deviance $=1659.6(107$

df)

$\mathrm{R}^{2}=0.11$

Alouatta spp.

(Intercept)

0.0561

$-0.002$

4.119

$6.13 \mathrm{e}-05$

0.00633

$* * *$

$-2.767$

$* *$

Null deviance $=177.5(158 \mathrm{df})$

Residual deviance $=163.0(157 \mathrm{df})$

$\mathrm{R}^{2}=0.08$

Pithecia spp.

(Intercept)

$-0.194$

$-0.616$

0.53888

$-3.176$

0.00184

$-0.005$

1.711

0.08939

Null deviance $=148.2(141 \mathrm{df})$

Residual deviance $=127.5(139 \mathrm{df})$

$\mathrm{R}^{2}=0.14$

Cebus apella

(Intercept)

$-0.366$

$-1.239$

0.217387

$5.06 \mathrm{e}-07$

$-5.269$

0.092298

0.004

1.695

0.000692

$\%$ unflooded

0.023

3.470

***

$\mathrm{R}^{2}=0.31$

Residual deviance $=125.0(140 \mathrm{df})$

Ateles spp.

(Intercept)

population density

1.646

7.744

$8.89 \mathrm{e}-12$

1.796

0.0756

Null deviance $=1150.0$ (99 df)

Residual deviance $=1102.6(98 \mathrm{df})$

$\mathrm{R}^{2}=0.04$

Lagothrix spp.

(Intercept)

1.932

8.207

$6.14 \mathrm{e}-13$

0.000117

$* * *$

0.037

4.004

0.000270

2.451

0.015900

$\mathrm{ns}$

**

0.010

$\mathrm{R}^{2}=0.44$ 
Table A4. Results of minimal Generalized Linear Models of proportional faunal depletion of census sectors, for those sectors for which field surveys allowed a full census of the human population $(n=41)$. A quasi-binomial error structure was specified. Significance levels refer to: $\mathrm{p}<0.1$ (.); $\mathrm{p}<0.05(*) ; \mathrm{p}<0.01(* *) ; \mathrm{p}<0.001(* * *)$.

\begin{tabular}{|c|c|c|c|c|}
\hline Variables & Coefficient & $\mathrm{t}$ & $\mathrm{p}$ & Significance \\
\hline \multicolumn{5}{|l|}{ Tapirus terrestris } \\
\hline (Intercept) & 1.9656 & 2.20 & 0.034 & $*$ \\
\hline city distance $(\mathrm{km})$ & -0.0081 & -4.22 & 0.000 & $* * *$ \\
\hline population density (-km2) & 0.7065 & 4.68 & 0.000 & $* * *$ \\
\hline terra firme $(\%)$ & -3.1436 & -2.67 & 0.011 & $*$ \\
\hline \multicolumn{5}{|l|}{ Null deviance $=28.3(40 \mathrm{df})$} \\
\hline Residual deviance $=3.3(37 \mathrm{df})$ & & $\mathrm{R}^{2}=0.88$ & & \\
\hline \multicolumn{5}{|l|}{ Tayassu pecari } \\
\hline (Intercept) & 1.2301 & 0.92 & 0.364 & $\mathrm{~ns}$ \\
\hline population density (-km2) & 0.9530 & 3.60 & 0.001 & $* * *$ \\
\hline terra firme $(\%)$ & -4.2309 & -2.70 & 0.011 & $*$ \\
\hline \multicolumn{5}{|l|}{ Null deviance $=26.8(40 \mathrm{df})$} \\
\hline Residual deviance $=6.1(38 \mathrm{df})$ & & $\mathrm{R}^{2}=0.77$ & & \\
\hline \multicolumn{5}{|l|}{ Pecari tajacu } \\
\hline (Intercept) & 3.5157 & 3.16 & 0.003 & $* *$ \\
\hline city distance $(\mathrm{km})$ & -0.0005 & -0.18 & 0.860 & ns \\
\hline population density (-km2) & -0.8943 & -1.91 & 0.065 & . \\
\hline terra firme $(\%)$ & -8.2043 & -4.18 & 0.000 & $* * *$ \\
\hline city distance:pop density & -0.0025 & -2.78 & 0.009 & $* *$ \\
\hline pop density: terra firme & 2.9696 & 3.41 & 0.002 & $* *$ \\
\hline \multicolumn{5}{|l|}{ Null deviance $=19.6(40 \mathrm{df})$} \\
\hline Residual deviance $=2.0(35 \mathrm{df})$ & & $\mathrm{R}^{2}=0.90$ & & \\
\hline \multicolumn{5}{|l|}{ Mazama americana } \\
\hline (Intercept) & 1.8195 & 1.39 & 0.172 & ns \\
\hline population density $(-\mathrm{km} 2)$ & -1.4137 & -2.91 & 0.006 & $* *$ \\
\hline terra firme $(\%)$ & -6.7794 & -3.48 & 0.001 & $* *$ \\
\hline pop density: terra firme & 3.0504 & 3.48 & 0.001 & $* *$ \\
\hline \multicolumn{5}{|l|}{ Null deviance $=10.0(40 \mathrm{df})$} \\
\hline Residual deviance $=4.3(37 \mathrm{df})$ & & $\mathrm{R}^{2}=0.58$ & & \\
\hline \multicolumn{5}{|l|}{ Crax/Mitu spp. } \\
\hline (Intercept) & 1.8656 & 1.04 & 0.307 & ns \\
\hline city distance $(\mathrm{km})$ & 0.0351 & 2.18 & 0.036 & $*$ \\
\hline population density $(-\mathrm{km} 2)$ & -1.8255 & -3.05 & 0.004 & $* *$ \\
\hline terra firme $(\%)$ & -7.3161 & -2.53 & 0.016 & $*$ \\
\hline city distance: terra firme & -0.0365 & -1.96 & 0.058 & . \\
\hline pop density: terra firme & 4.2198 & 3.64 & 0.001 & $* * *$ \\
\hline \multicolumn{5}{|l|}{ Null deviance $=22.4(40 \mathrm{df})$} \\
\hline Residual deviance $=5.2(35 \mathrm{df})$ & & $\mathrm{R}^{2}=0.77$ & & \\
\hline \multicolumn{5}{|l|}{ Pithecia spp. } \\
\hline (Intercept) & -2.9186 & -1.35 & 0.185 & ns \\
\hline city distance $(\mathrm{km})$ & 0.0742 & 3.16 & 0.003 & $* *$ \\
\hline population density (-km2) & -0.7883 & -1.66 & 0.107 & ns \\
\hline
\end{tabular}


terra firme $(\%)$

city distance:pop density

city distance: terra firme

pop density: terra firme

Null deviance $=14.7(39 \mathrm{df})$

Residual deviance $=4.5$ (33 df)

Cebus apella

(Intercept)

city distance $(\mathrm{km})$

population density (-km2)

terra firme $(\%)$

city distance:pop density

city distance: terra firme

pop density: terra firme

Null deviance $=15.0(40 \mathrm{df})$

Residual deviance $=5.8(34 \mathrm{df})$

Ateles spp.

(Intercept)

population density $(-\mathrm{km} 2)$

terra firme $(\%)$

Null deviance $=15.2(32 \mathrm{df})$

Residual deviance $=4.3(30 \mathrm{df})$

Lagothrix spp.

(Intercept)

city distance $(\mathrm{km})$

terra firme $(\%)$

Null deviance $=15.2(32 \mathrm{df})$

Residual deviance $=4.3(30 \mathrm{df})$

Chelonoidis spp.

(Intercept)

city distance $(\mathrm{km})$

population density (-km2)

terra firme $(\%)$

city distance: terra firme

Null deviance $=21.3(40 \mathrm{df})$

Residual deviance $=3.9(36 \mathrm{df})$
$-1.4343$

$-0.0037$

$-0.45$

$-2.35$

0.657

$-0.0838$

$-3.03$

2.3592

2.50

0.025

0.005

0.017

$\mathrm{R}^{2}=0.70$

0.7842

0.0526

$-1.8957$

$-7.5062$

$-0.0058$

$-0.0527$

4.8127

0.37

2.19

0.717

0.036

0.008

0.033

0.007

0.056

0.001

3.48

$\mathrm{R}^{2}=0.61$

3.7744

2.44

0.021

0.7124

2.24

$-3.52$

0.033

0.001

$\mathrm{R}^{2}=0.72$

5.2049

5.47

$-5.62$

0.000

0.000

0.001

$* * *$

$-5.1973$

$-3.71$

$\mathrm{R}^{2}=0.89$

1.6997

0.87

0.392

ns

0.0298

2.87

0.007

0.004

**

3.11

0.187

0.006

$-3.0733$

$-1.34$

$-2.91$

ns

**

$R=0.82$ 


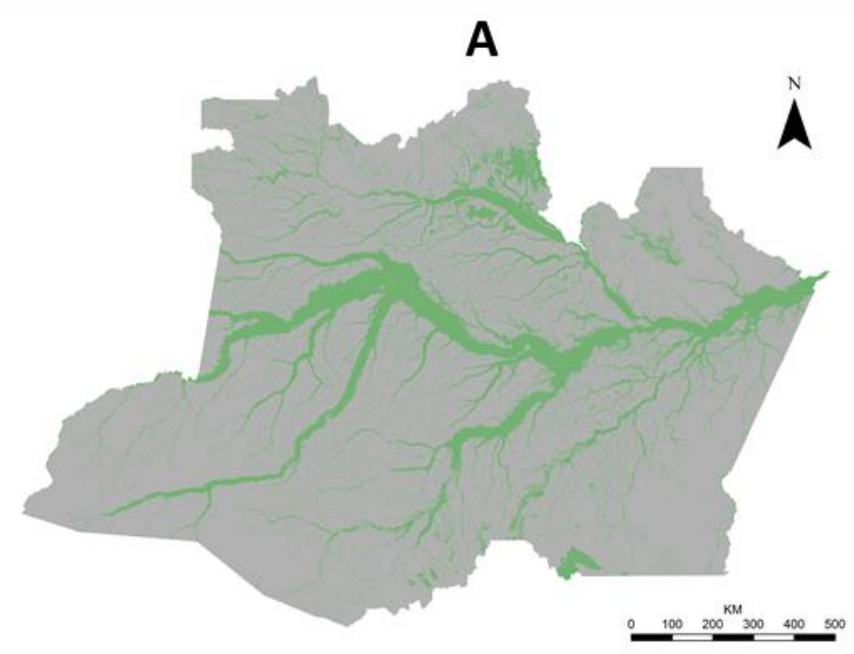

B

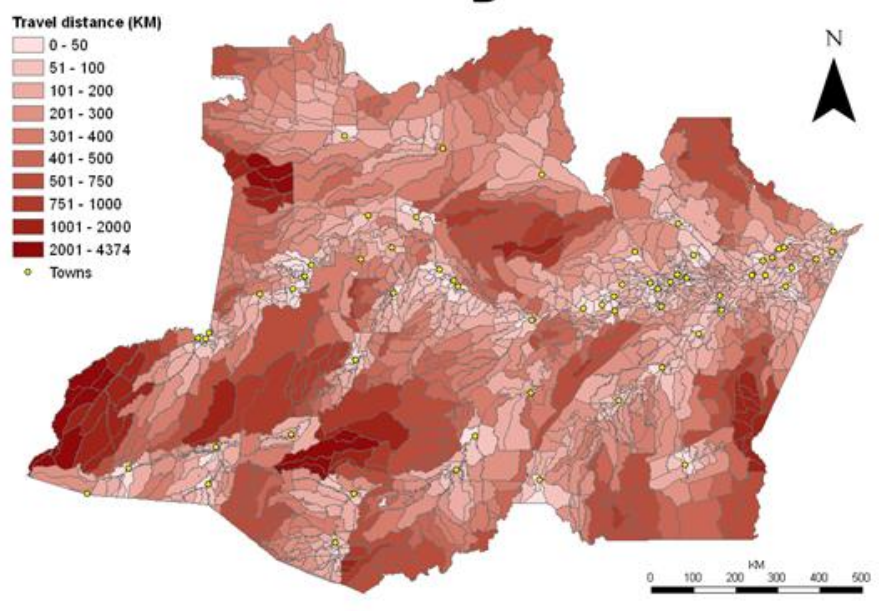

C

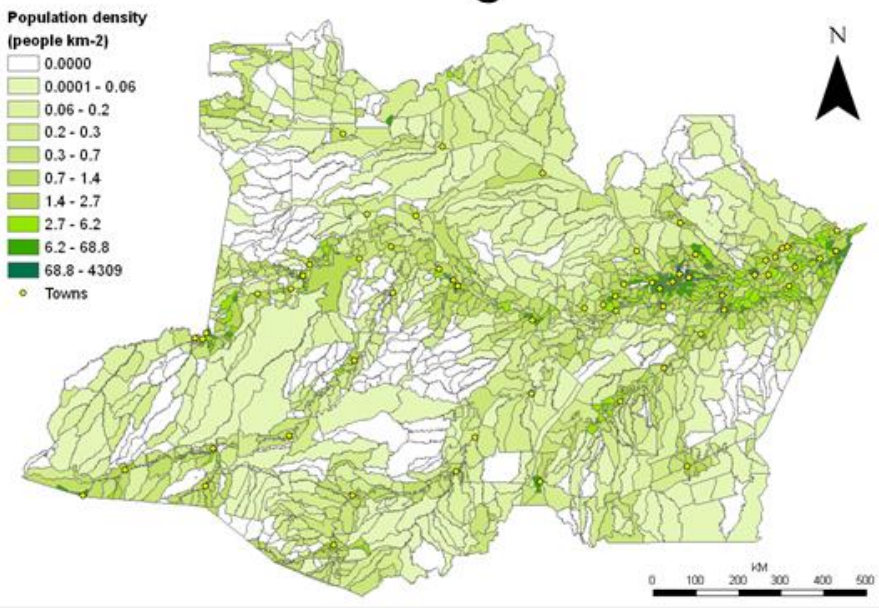

Figure A1. Variables assigned to census sectors: (A) Land-form based on coverage of flooded várzea (green) and unflooded terra firme (gray); (B) Travel distances to the local urban center (calculated from network analysis; Parry et al. 2010a), and (C) Human population density calculated from the IBGE 2007 population census. 


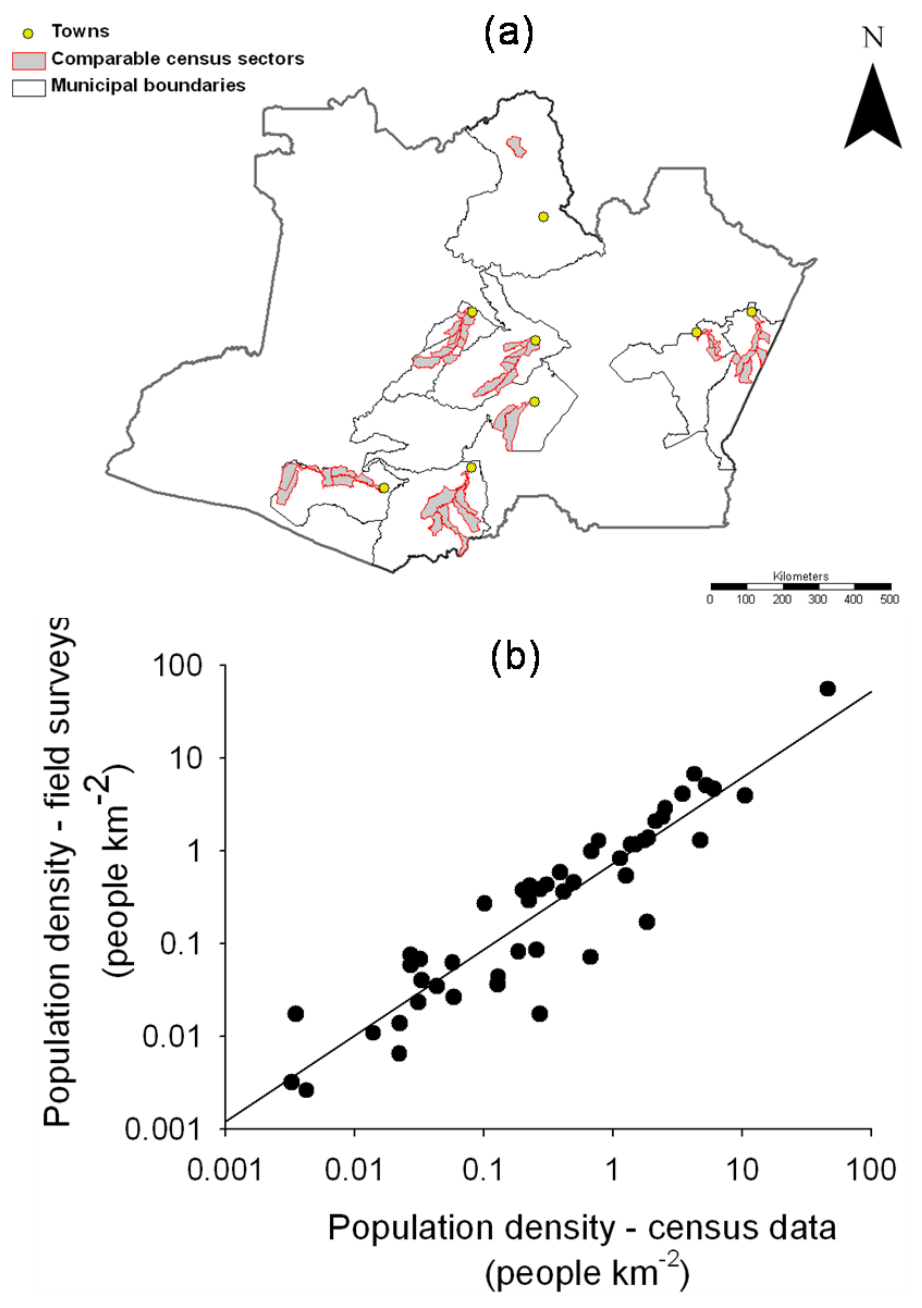

Figure A2. (A) Map of Amazonas state, Brazil, showing census sectors for which we compared governmental 2007 census data and our own surveys, based on field observations, interviews, and local and state health databases. Note this also includes population data from the R. Maués (far right), collected during a pilot study. (B) Comparison of 2007 population density estimates from the national census of the Brazilian Institute of Geography and Statistics (IBGE) and our field surveys. Pearson correlation $(\log (\mathrm{POPibge}+1) \sim$ $\log ($ POPfield +1$))=0.983, \mathrm{n}=52, \mathrm{p}<0.001$. 


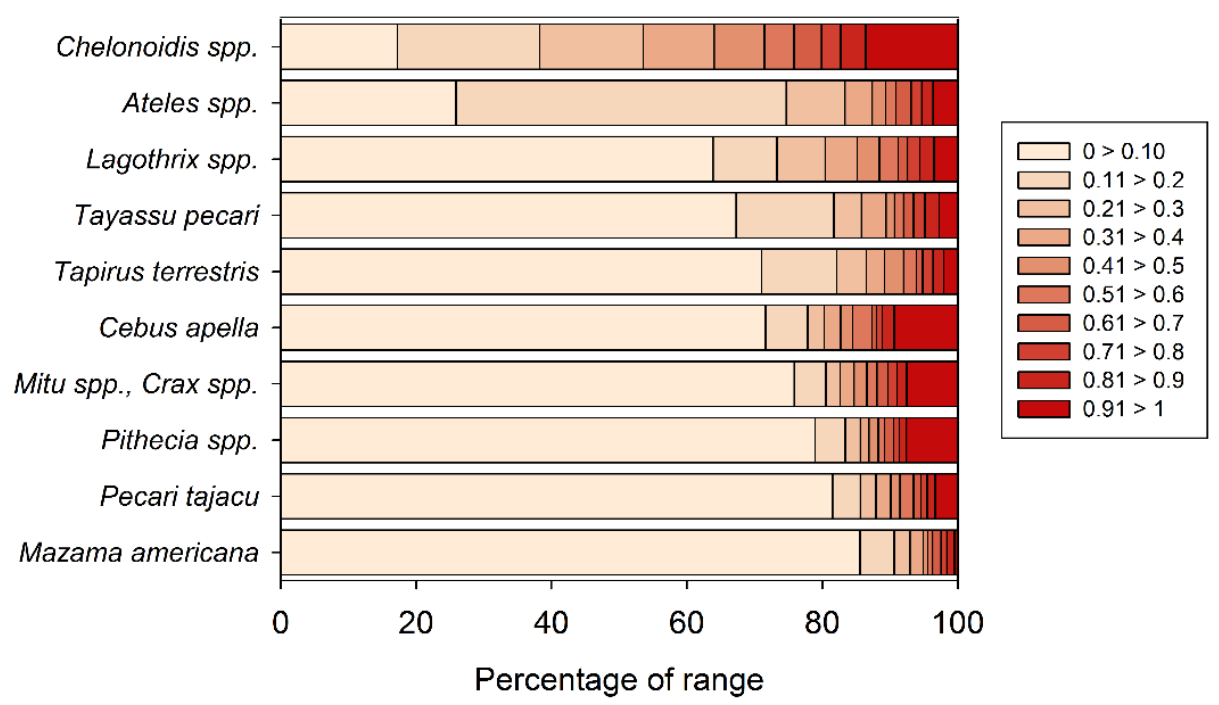

Figure A3. Depletion levels estimated for 10 species of large vertebrate, within their known geographic range distribution within Amazonas state, Brazil. 

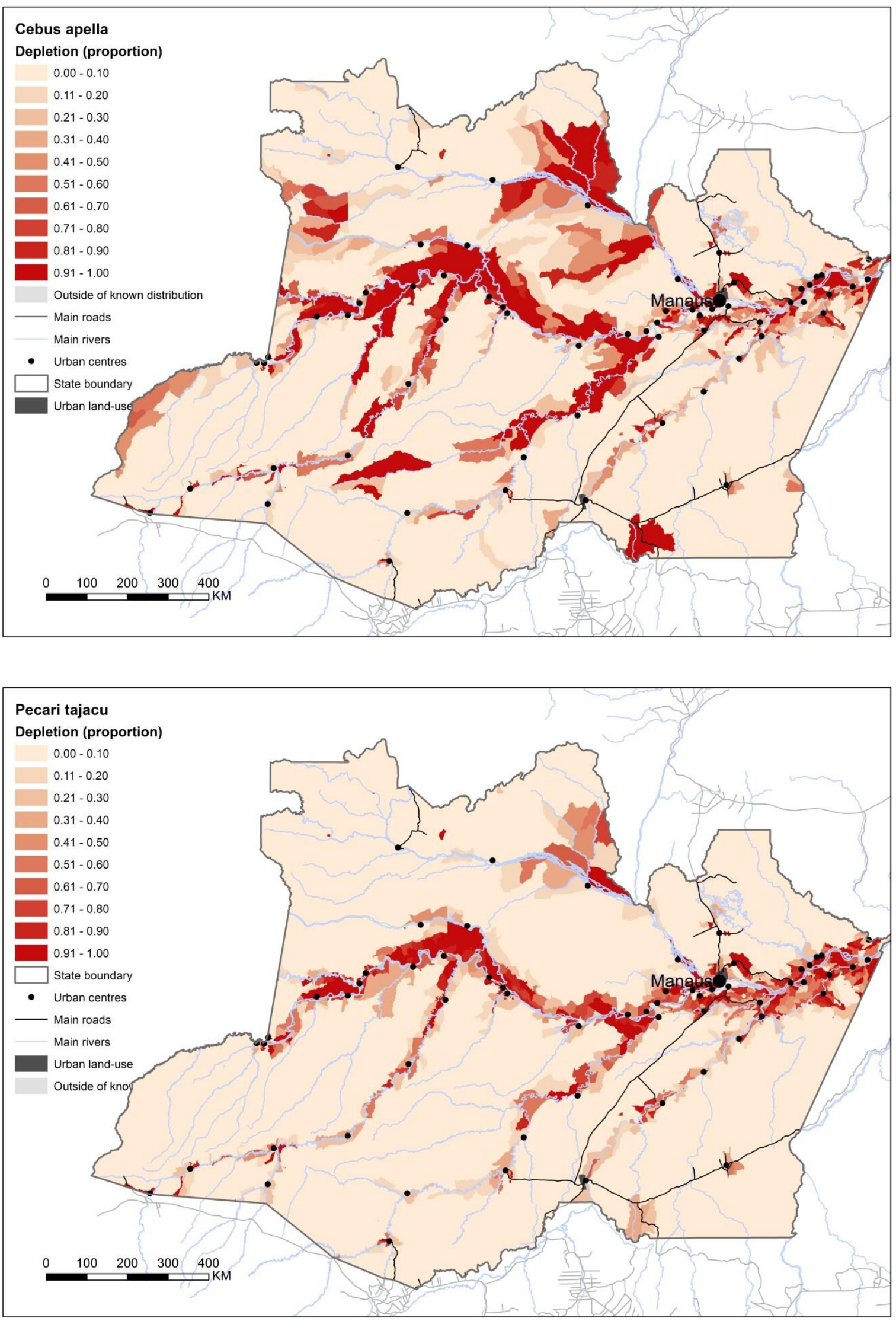

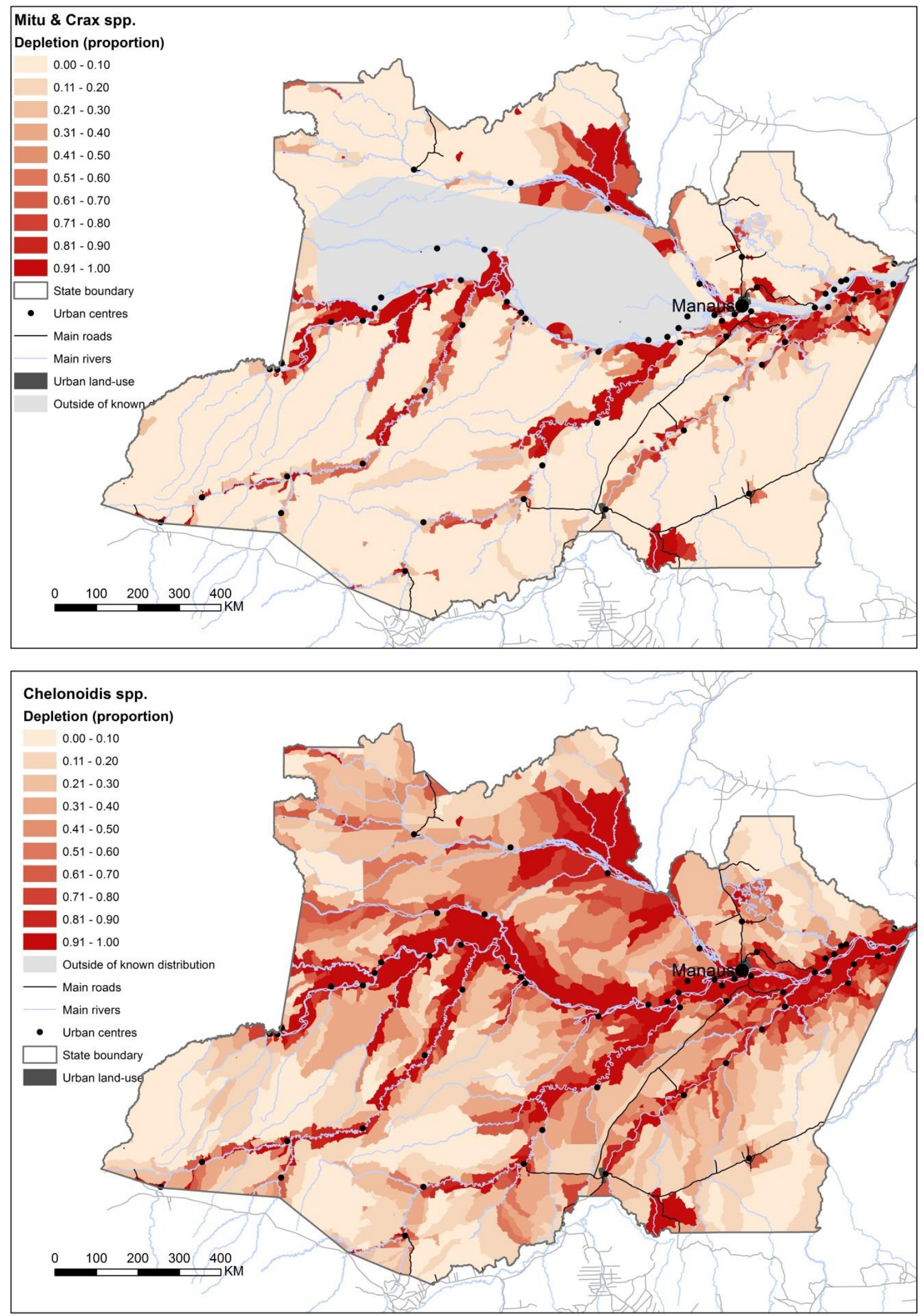

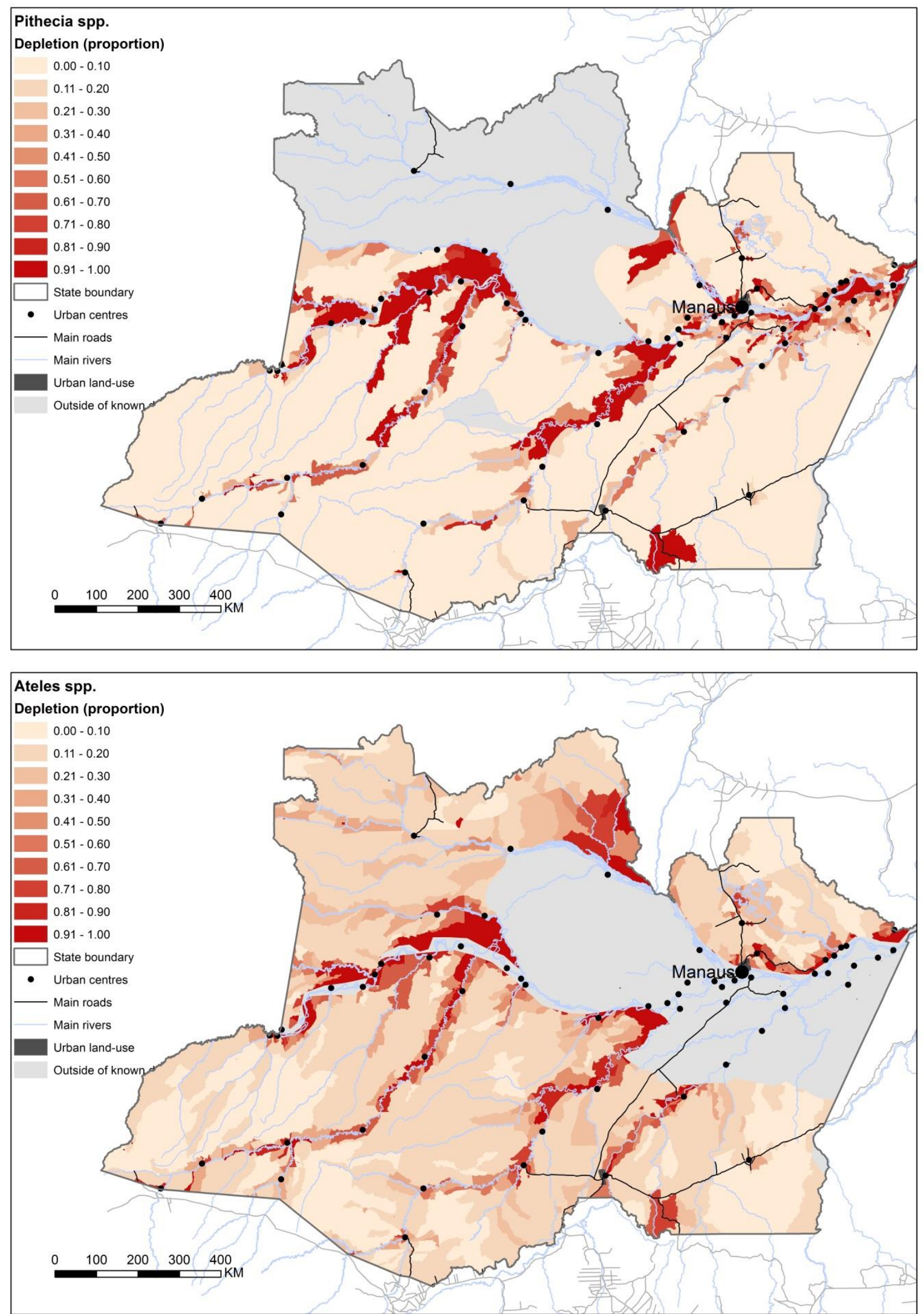

Figure A4. Predicted depletion levels of large vertebrates within census sectors in Amazonas State, Brazil, based on species-specific predictive models that used human population density, coverage of terra firme upland, and travel distance to the nearest urban center. 